IJMS 26 (1), 99-145 (2019)

How to cite this article:

Ibrahim, Y., \& Ahamat, A. (2019). Interpersonal communication skills of nurse managers and nursing performance. International Journal of Management Studies, 26(1), 99-145.

\title{
INTERPERSONAL COMMUNICATION SKILLS OF NURSE MANAGERS AND NURSING PERFORMANCE
}

\author{
YULIANI IBRAHIM* \\ School of Graduate Studies, Management \& Science University, \\ Shah Alam, Selangor, Malaysia \\ AMIRUDDIN AHAMAT
Faculty of Technology Management \& Technopreneurship,
Universiti Teknikal Malaysia Melaka \\ *Corresponding Author:yulianiibr@gmail.com
}

\begin{abstract}
Interpersonal communication between the nurse manager and the executing nurse is needed for the continuity and productivity of the profession, whereby one's productivity is strongly influenced by performance. Therefore, this study aims to know the extent of the relationship between the interpersonal communication skills (leadership, communication process, motivation, and negotiation skills) of the nurse managers, (independent variable), and the performance of nurses, (dependent variable) at Tgk. Chik Ditiro Sigli Hospital and Harapan Bunda Banda Aceh Hospital in Indonesia. The population in this study were all nurses at the two hospitals consisting of 331 respondents. The results showed a significant relationship between the interpersonal communication skills of the nurse managers and the performance of the nurses at the two hospitals. The test results also showed that there was a significant difference between the interpersonal communication skills of the nurse managers and the performance of nurses at Tgk. Chik Ditiro Sigli Hospital and at Harapan Bunda Banda Aceh Hospital. The only variable that showed similarities between the two hospitals was motivation.
\end{abstract}


Keywords: Interpersonal communication, leadership, communication process, negotiation, motivation, performance.

Received: 17/8/2019 Revised: 15/10/2019 Accepted:30/12/2019 Published: 31/1/2020

\section{Introduction}

Socio-economic contexts, which symbolise a society, are so intertwined that they are distinguishable but indivisible (Pillai \& Ahamat, 2018). Hence, the existence of hospitals as social and economic entities seems crucial. A hospital is an essential part of a health system. In the health services network, it becomes the central node that serves as a referral centre. It is an organisation categorised as a labour intensive and capital intensive industry, which requires intensive technology and intensive skills. Managing human resources in a hospital is a complex and challenging task. Nowadays, hospitals have developed into a service industry. As a service industry, the role of human resources is highly vital (Katon, 2014). Nursing services at a hospital is the most significant component of the healthcare system. In line with the development of science and technology and the increasing demand for healthcare services from the community, a hospital, regarded as a place of healthcare and nursing services, is required to balance the expectations and needs of the community with professional, quality services, especially the nursing services. Building expertise in all aspects of communication is essential to managerial success. As Brice (2000, p. 18) puts it, "although some management functions, such as planning, organising and controlling, can be logically separated, communication forms the core of management activities and bypasses all phases of the management process. Communication within the organisation is a management function that must be systematic, continuous, and fully integrated into the organisational structure by encouraging the exchange of views and ideas. In addition, communication involves language, which is bound and influenced by culture, and increasing complexity."

Practical interpersonal communication skills are essential to social interaction and the building and maintaining of relationships. Poor communication skills can cause irrevocable damage to relationships; and affects productivity, satisfaction, performance, morale, trust, 
respect, self-confidence, and even physical health (UnAnge, 2008). Communication happens in different organisations. Government organisations prioritise on the principles of kinship and togetherness that can make the process of communication more casual or informal; while profit-oriented private companies prioritise on efficiency and effectiveness of communication skills so that established communication becomes more stiff or formal.

Based on the background of the study, the problems can be formulated as follows: Is there a relationship between the interpersonal communication skills of nurse managers and the nurses' performance at Tgk. Chik Ditiro Sigli Hospital and Harapan Bunda Banda Aceh Hospital, Indonesia? and are there any differences in the interpersonal communication skills of the nurse managers and the nurses' performance between Tgk. Chik Ditiro Sigli Hospital and Harapan Bunda Banda Aceh Hospital, Indonesia. The objective of this research is to examine the relationship of interpersonal communication skills of nurse managers (in the form of leadership, communication process, motivation, and negotiation) with nurses at the Tgk. Chik Ditiro Sigli Hospital and at Harapan Bunda Banda Aceh Hospital. The location of the study was at Tgk. Chik Ditiro Sigli Hospital, a local state-owned hospital, and Harapan Bunda Banda Aceh Hospital, a private hospital.

\section{Literature Review}

Interpersonal communication skills encompass the ability to respond to the needs of staff positively, fostering a non-discriminatory work environment where staff can develop their full personal potential and delegate authority (Avkiran, 2000). The competence of interpersonal communication consists of a set of skills, knowledge of communication, and self-evaluation. Competent interpersonal communication skills include self-disclosure, possessiveness and thoughts, and descriptiveness and support (Robinson, 2006). Robbins and Hunsaker (as cited in Matin, 2010) reviewed a large number of studies and synthesised interpersonal skills that appeared in most of the studies. These skills are divided into three categories: leadership, communication process, and motivation.

Interpersonal leadership skills are related to leadership styles, conflict management, meeting conditions, team building, and promoting 
change. Meanwhile, the communication process includes sending messages, listening, and providing feedback. Similarly, motivation consists of goal setting, clarifying expectations, persuading and empowering. Another significant interpersonal skill is negotiation skills. In this paper, the model presented by Robbins and Hunsaker (as cited in Matin et al., 2010) was applied to test and measure the variables of managerial interpersonal communication skills. The sections and components of the model mentioned are shown in Table 1.

Table 1

Conceptualisation of Interpersonal Communication Skills

\begin{tabular}{lll}
\hline \multicolumn{1}{c}{ Concept } & \multicolumn{1}{c}{ Dimension } & \multicolumn{1}{c}{ Component } \\
\hline & & \multicolumn{1}{c}{$\begin{array}{c}\text { Leadership style } \\
\text { Handling conflict } \\
\text { Running meetings } \\
\text { Team building } \\
\text { Promoting change }\end{array}$} \\
& & \\
Interpersonal & Process of & Sending messages \\
sommunication & communication & Listening \\
& & Providing feedback \\
& & Goal setting \\
& & Clarifying expectations \\
& Motivation & Persuading \\
& & Empowering \\
& & Negotiating \\
\hline
\end{tabular}

Source. Robbins \& Hunsaker (as cited in Matin et al., 2010).

\section{Leadership Style}

Several leadership styles greatly influence a leader's success in inspiring the behaviour of his or her subordinates. Usman (2009) stated that researchers had identified two styles of leadership: (1) task-oriented and (2) subordinate- or employee-oriented. The task-oriented style is more concerned with the completion of tasks with tight supervision to finish the task according to the leader's requirements. A good relationship with subordinates is ignored, and 
subordinates must work hard, be productive, and timely. In contrast, a subordinate-oriented leadership style tends to pay more attention to good relationships with subordinates, motivating them rather than closely monitoring, and more importantly, sensitive to the feelings of subordinates.

According to Ilyas (as cited in Novitasari, 2014), one of the organisational factors that affect performance is leadership. The role of leaders in organisations is to facilitate the functioning and responsibility of each of its members to remain focused. Employees generally need good leadership. Successful leaders must lead their organisations by creating a pleasant atmosphere or conditions to allow each employee to contribute totally to the work assigned. It can be done by educating members of the organisation with new skills, encouraging employees to deal with something that they are afraid of doing, also by listening to employee complaints or ideas, hopes, criticisms and suggestions. and other forms of partners or subordinates. Another aspect that is also important and must be considered by leaders is to facilitate mental and technical support for employees which will significantly determine the performance of leaders and employees.

\section{Handling Conflict}

The emergence of conflict is normal due to various perceptions, social background, education, personality, shared values, expectations, and experiences. Usman (2009, p. 22) pointed out that conflict exists as either "1) a conflict between two or more against one thing or more with fellow members of another organisation, or 2) a conflict with one's own conscience." According to Engkoswara and Komariah (2010), "conflict is any kind of antagonistic interaction between two or more parties." This conflict of interest differs in intensity depending on the means employed. Each party wants to defend the values they consider true and force others to recognise those values either subtly or roughly. Murni and Veithzal (2009) stated another definition of work conflict as the incompatibility between two or more members or groups (within an organisation/company) that must share limited resources or work activities and due to their differences in status, purpose, values and/or perception. Work conflict can also be interpreted as the behaviour of a member(s) of the organisation who are devoted to opposing another member(s). In addition, conflict can be defined as differences, disagreements, and disputes. 
However, it is generally understood that the organisation demands cooperation among groups because only then can the organisation move towards a higher level of effectiveness. In other words, cooperation must be fostered and developed in teamwork. Climate collaboration and functional interaction between groups often determine the effectiveness of the organisation as a whole. Siagian (2006) stated that "one of the problems that are often a barrier to the realisation of organisational effectiveness is a large number of dysfunctional personnel used to engage in unfeasible competition or competition between the various groups that should work together. It is undeniable that competition and conflict arises easily in intergroup relationships due to some factors such as goal differences, value systems, efforts and interests."

Murni and Veithzal (2009, p. 14) stated that "conflict is usually caused by several factors, such as communication factors, task structure or organisation structure, personal factors to environmental factors." Moreover, Murni and Veithzal (2009, p. 8) explained that "communication factors can be a cause of conflict when members of an organisation cannot or do not want to understand and understand each other in various ways within the organisation. The occurrence of misunderstanding when communicating can also lead to conflict." The team is defined as a group with complementary skills and is committed to achieving common goals effectively and efficiently (Hunsaker, 2001).

\section{Process of Communication}

De Vito (as cited in Liliweri, 2011) said that "communication is referred to as a process to emphasise "something" that always changes or always moves. If we mention "process", then it is always connoted with "activity," or an activity that is "non-static." Liliweri (2011) expounded that "the process of communication is demonstrated by a series of stages or steps where something is changing, the people involved in the communication change their thoughts and opinions and actions. Everyone who follows the communication process will have the opportunity to be more productive in every aspect of their profession". Figure 1 explains the communication process involving five basic stages elaborated by Berlo, Chartier, Davis, Hein, Hewitt, Jonhson, Long, Prophit, Miller, and Pluckhan ( as cited in Monica, 1998). 
IJMS 26 (1), 99-145 (2019)

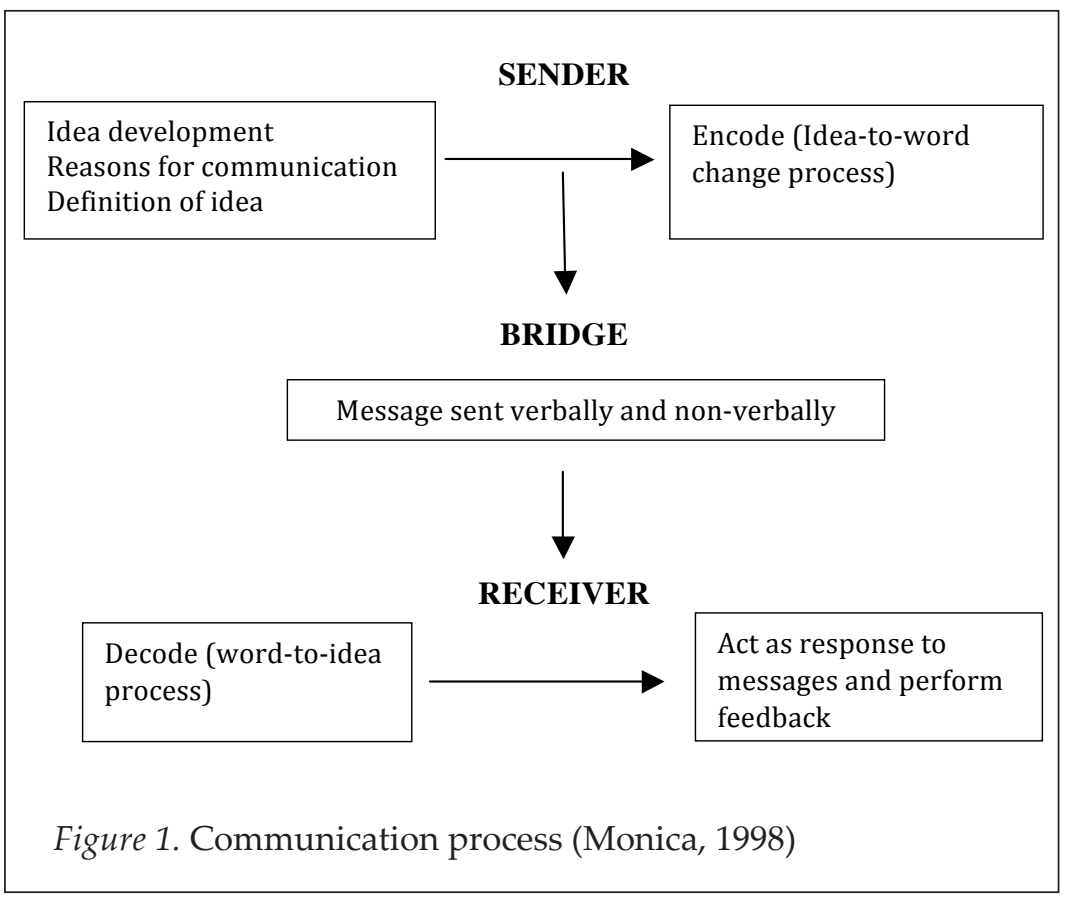

Once the idea is 'translated' into the selected language, the message will be transmitted by the sender through selected verbal and/or nonverbal channels. The receiver of the message, which enters the sender's channel, will receive the message and 'translates' from a language to an idea. The receiver of the information will act in response to the message delivered. The message can be saved or ignored; the receiver communicates another idea to the sender, or performs the task in response to the message.

Davis (as cited in Monica, 1998) stated emphatically that "the sender of the message must think before sending the information, this stage is very important." After the sender has a clear idea in his mind, he then selects a language that matches the idea presented. He also needs to determine which body language to use. Keep in mind that leadership and management involve recognisable strategies for all behaviours and selecting an appropriate language that is most likely to relay the messages accurately is essential. Whatever the receiver does in response to the sender's message is called feedback. Evaluating feedback is a method from the sender of a message to evaluate whether 
the message is received following its original intent. Berlo (as cited in Usman, 2009) said that "validation is very important because humans communicate and receive messages according to their own attitude, knowledge and experience."

Chitty (2001) defines communication as a complicated exchange between thoughts, ideas, or information, at least on two levels: verbal and non-verbal. Therefore, communication begins when two or more people are aware of each other's presence. However, what happens if the exchange of thoughts, ideas, and information does not have the same meaning for both the sender and the receiver of the message. Marquis and Huston (2010) stated that "the internal and external atmosphere also affects communication. The internal atmosphere includes the value, feelings, temperament, and level of sender and receiver strands. Weather conditions, temperature, time placement, and the atmosphere of the organisation itself is part of the external atmosphere. The external atmosphere also implies status, power, and authority as an obstacle to manager-employee communication".

Furthermore, Marquis and Huston (2010) stated that "because everyone is different, so is making decisions and looking at things differently, usually reviewing the external atmosphere is easier than the internal atmosphere. In assessing the internal mood, remember that the human mind perceives the thing to recognise. Generally, unexpected things are ignored or misunderstood. In other words, the receiver cannot communicate if the message does not match their expectation. Therefore, effective communication requires the sender to determine what the receiver sees and hears". Mikanowicz and Shank (2009) said "a sender will check each (intent/perception) of the message he sends so that the message received by the receiver has the same meaning/perception with the intent of the sender." Furthermore, Mikanowicz and Shank (2009) emphasised that "the difference in perception between sender and receiver when communicating can be suppressed only if the individual is able to see himself (self-concept) and see others as it is, this is because self-concept affects individual perception of others."

\section{Motivation}

The number and quality of work completed by managers directly reflect their motivation and the employees. Why are some managers or staff 
more motivated than others? What can an unmotivated manager do to influence the staff? What can the manager do to help unmotivated staff? The motivation problems facing managers are complex. To respond to unmotivated staff, managers need to understand the relationship between motivation and behaviour (Marquis \& Huston, 2010). Motivation is one tool that belongs to the superior so that the subordinates will work hard and work smart as expected. Knowledge of motivation patterns helps managers understand the work attitude of their respective employees. Managers can motivate their employees in different ways according to their characteristics.

Usman (2009) pointed out that "motivation is very important for managers to improve the performance of subordinates because the performance depends on motivation, ability, and environment." Mill (as cited in Marquis \& Huston, 2010) said that motivation is the "power in the individual, affecting the power or directing behaviour". Lee (as cited in Marquis \& Huston, 2010) stated that "motivation, coaching and empowerment are not merely management jargon: they should be a resource you can use every day." Leaders should apply techniques, skills, and knowledge about motivational theories to help nurses achieve what they want from work. At the same time, all these individual objectives should complement organisational goals. Managers have a primary responsibility for meeting organisational goals, for example achieving acceptable levels of productivity and quality. Stoner and Freeman (1995) noted that "motivating is the management process for influencing human behaviour based on knowledge of what makes people move." Usman (2009) argued that "negotiation is a process of interaction of two or more parties whom each have a different purpose, but they try through argumentation and persuasion to find a mutually agreeable solution." Negotiation skills do not just show up. As with any other skill, this skill needs to be sharpened. Some skills need to be deepened, such as optimism, courage, tolerance, ambition, and humour (Hariwijaya, 2008).

\section{Performance}

Gaspersz (1997) stated that "performance is built of quality, and quality is composed of everything free from deficiencies or damage generated by the organisation to satisfy all elements related to the organisation both internally and externally." According to Nursalam (2014), performance can be viewed as a process or a result of work. 
Performance is a process of how work takes place to achieve work. However, the work itself also shows performance.

Wibowo (2008) posits that "working behaviour is seen from the work of vigorous, disciplined, and responsible individuals carrying out tasks according to established standards, have high motivation and workability and directed to the achievement of organisational goals while the work is the final process of an activity which members of the organisation is striving in achieving the goal." Based on the above opinion, it can be concluded that the performance of nurses in providing nursing care reflects their overall behaviour and abilities. Meanwhile, the work of nurses can be seen from the final process of nursing care, one of them is documenting nursing care given to the patient, which includes assessment, diagnosis, planning, implementation, and evaluation.

In addition, nurses are retiring at an accelerating rate, and it has been proposed that efforts should be made to retain nurses who are approaching retirement (Bernard Hodes Group, 2006). The ageing workforce raises performance issues from an $\mathrm{HF} / \mathrm{E}$ perspective because perceptual, cognitive, and physical abilities decline with age (Sanders \& McCormick, 1993).

Partly due to the nursing shortage, the nursing workforce is overloaded in terms of the number of patients that nurses oversee, the number of hours that nurses work, and the number of tasks that nurses perform. For example, many nurses work 12 hours or more per day (Houle, 2001) and often work without breaks or meals (Rogers, Hwang, \& Scott, 2004). Increases in such nursing workload can increase the risk of burnout and job dissatisfaction, which may contribute to the nursing shortage (Aiken, Clarke, Sloane, Sochalski, \& Silber, 2002).

Related research on the performance of nurses was conducted by Harmiyati (2016), who concluded that the characteristics of individuals (age, sex, marital status, and education) have no relationship with the performance of nurses at public health centres (Puskesmas) while the working period is related to the performance of the Puskesmas nurses at the Puskesmas of Palembang city. A significant relationship between individual capability (knowledge, attitude, and skills) and the performance of nurses at the Palembang Public Health Centre was observed. Similarly, a significant relationship between 
the characteristics of the organisation (leadership, work culture, compensation, and workload) and the performance of nurses at Palembang Public Health Centre.

A nurse who has a reasonable workload will produce excellent performance, six times better compared to nurses who have poor workloads; while a nurse who has good knowledge will produce seven times better performance compared to a nurse who has less knowledge. Similarly, nurses who have a positive attitude will produce 37 times excellent performance compared to nurses who have a less positive attitude; while a nurse who has excellent skills will produce good performance six times better compared to a nurse who has fewer good skills.

A study on organisational commitment mirrored in previous literature showed a negative relationship with intention to leave. The findings of the study in a Malaysian nursing context posited that the effects of moral obligation is a mediating variable in the relationship between organisational commitment and the intention to leave among nurses who work in Malaysian public hospitals.

Therefore, factors that enable the management and employers to attain a better understanding are crucial and serve as guidelines to draft retention strategies (Omar, Mohamed Anuar, Abdul Majid, \& Johari, 2012). This is reflected in one of the variables presented, the motivation factors in the context of interpersonal communication skills. The research framework was constructed to address the underlying research objectives.

\section{Research Framework}

Independent Variable

Nurse managers' interpersonal communication skills:

1. Leadership

2. Communication process

3. Motivation

4. Negotiation

Figure 2. Research framework
Dependent Variable

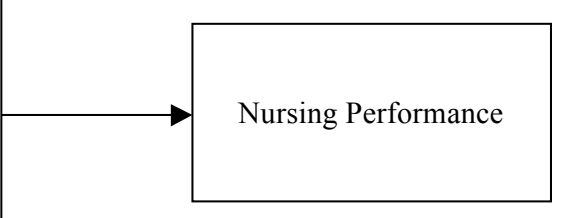


Consequently, to operationalize the research framework as proposed in Figure 2, this study suggests an appropriate methodological approach.

\section{Methodology}

This research used a cross-sectional and comparative study. The cross-sectional study is a study concerning the dynamics of correlation between risk factors and effects, by way of approach, observation or data collection at a time (point time approach) at the same time. Meanwhile, comparative research is a study that tends to compare equations and differences as a phenomenon to find what factors, or what situation causes the occurrence of a particular event (Notoatmodjo, 2012). The location of the research was at the Harapan Bunda Banda Aceh Hospital and Tgk. Chik Ditiro Sigli Hospital. The duration allocated for data collection was four months from September 2015 to December 2015. Furthermore, this study was to examine the interpersonal communication skills (leadership, communication process, motivation, and negotiation skills) of the nurse managers (independent variable) with the performance of nurses (dependent variable) in the context of selected hospitals in Indonesia. The operational definition is analysed in the following tables.

\section{Operational Definition}

\section{Table 2}

Operational Definitions to Identify Relationships between the Interpersonal Communication Skills of the Nurse Managers and the Performance of Nurses

\begin{tabular}{|c|c|c|c|c|c|c|}
\hline No. & Variable & $\begin{array}{l}\text { Operational } \\
\text { Definition }\end{array}$ & $\begin{array}{l}\text { Measurement } \\
\text { Technique }\end{array}$ & Instrument & Scale & Result \\
\hline \multicolumn{7}{|c|}{ Dependent variable } \\
\hline 1 & $\begin{array}{l}\text { Nurse } \\
\text { Performance }\end{array}$ & $\begin{array}{l}\text { The } \\
\text { Workability } \\
\text { is shown by } \\
\text { nurses }\end{array}$ & $\begin{array}{l}\text { Distribute } \\
\text { questionnaire }\end{array}$ & $\begin{array}{l}\text { Questionnaire } \\
\text { with } 8 \\
\text { statements and } \\
\text { use of Likert } \\
\text { scale }\end{array}$ & Ordinal & $\begin{array}{l}\text { Good } \\
x \geq x \\
\text { Bad } \\
x<x\end{array}$ \\
\hline \multicolumn{7}{|c|}{ Independent Variable (interpersonal communication skills of nurse managers) } \\
\hline
\end{tabular}


IJMS 26 (1), 99-145 (2019)

\begin{tabular}{|c|c|c|c|c|c|c|}
\hline No. & Variable & $\begin{array}{l}\text { Operational } \\
\text { Definition }\end{array}$ & $\begin{array}{l}\text { Measurement } \\
\text { Technique }\end{array}$ & Instrument & Scale & Result \\
\hline \multicolumn{7}{|c|}{ Dependent variable } \\
\hline 1 & $\begin{array}{l}\text { Leadership of } \\
\text { nurse managers }\end{array}$ & $\begin{array}{l}\text { The ability } \\
\text { of nurse } \\
\text { managers in } \\
\text { managing } \\
\text { conflict, } \\
\text { conducting } \\
\text { meetings, and } \\
\text { developing } \\
\text { teamwork, } \\
\text { also making } \\
\text { some changes }\end{array}$ & $\begin{array}{l}\text { Distribute } \\
\text { questionnaire }\end{array}$ & $\begin{array}{l}\text { Questionnaire } \\
\text { with } 15 \\
\text { statements and } \\
\text { uses of Likert } \\
\text { scale }\end{array}$ & Ordinal & $\begin{array}{l}\text { Good } \\
x \geq x \\
\text { Bad } \\
x<x\end{array}$ \\
\hline 2 & $\begin{array}{l}\text { Communication } \\
\text { process of nurse } \\
\text { managers }\end{array}$ & $\begin{array}{l}\text { The ability } \\
\text { of nurse } \\
\text { managers in } \\
\text { delivering } \\
\text { information to } \\
\text { subordinates } \\
\text { and receiving } \\
\text { information } \\
\text { from } \\
\text { subordinates }\end{array}$ & $\begin{array}{l}\text { Distribute } \\
\text { questionnaire }\end{array}$ & $\begin{array}{l}\text { Questionnaire } \\
\text { with } 4 \\
\text { statements and } \\
\text { use of Likert } \\
\text { scale }\end{array}$ & & $\begin{array}{l}\text { Good } \\
x \geq x \\
\text { Bad } \\
x<x\end{array}$ \\
\hline 3 & $\begin{array}{l}\text { Nurse } \\
\text { managers' } \\
\text { motivation }\end{array}$ & $\begin{array}{l}\text { The ability } \\
\text { of nurse } \\
\text { managers in } \\
\text { motivating } \\
\text { subordinates } \\
\text { positively to } \\
\text { do work }\end{array}$ & $\begin{array}{l}\text { Distribute } \\
\text { questionnaire }\end{array}$ & $\begin{array}{l}\text { Questionnaire } \\
\text { with } 3 \\
\text { statements and } \\
\text { use of Likert } \\
\text { scale }\end{array}$ & & $\begin{array}{l}\text { Good } \\
x \geq x \\
\text { Bad } \\
x<x\end{array}$ \\
\hline 4 & $\begin{array}{l}\text { Nurse } \\
\text { managers' } \\
\text { negotiation }\end{array}$ & $\begin{array}{l}\text { The ability } \\
\text { of nurse } \\
\text { managers in } \\
\text { negotiating } \\
\text { agreement } \\
\text { with } \\
\text { subordinates }\end{array}$ & $\begin{array}{l}\text { Distribute } \\
\text { questionnaire }\end{array}$ & $\begin{array}{l}\text { Questionnaire } \\
\text { with } 4 \\
\text { statements and } \\
\text { use of Likert } \\
\text { scale }\end{array}$ & & $\begin{array}{l}\text { Good } \\
x \geq x \\
\text { Bad } \\
x<x\end{array}$ \\
\hline
\end{tabular}

Table 3

Operational Definition to Identify Differences in the Interpersonal Communication Skills of the Nurse Managers and the Performance of Nurses at Tgk. Chik Ditiro Sigli Hospital and Harapan Bunda Banda Aceh Hospital

\begin{tabular}{|c|c|c|c|c|c|c|}
\hline No & Variable & $\begin{array}{l}\text { Operational } \\
\text { Definition }\end{array}$ & $\begin{array}{l}\text { Measurement } \\
\text { Technique }\end{array}$ & Instrument & Scale & Result \\
\hline \multicolumn{7}{|c|}{ Dependent Variable } \\
\hline 1 & $\begin{array}{l}\text { Leadership of } \\
\text { nurse managers }\end{array}$ & $\begin{array}{l}\text { The ability } \\
\text { of nurse } \\
\text { managers in } \\
\text { managing } \\
\text { conflict, } \\
\text { conducting }\end{array}$ & $\begin{array}{l}\text { Distribute } \\
\text { questionnaire }\end{array}$ & $\begin{array}{l}\text { Questionnaire } \\
\text { with } 15 \\
\text { statements and } \\
\text { use of Likert } \\
\text { scale }\end{array}$ & Ordinal & $\begin{array}{l}\text { Good } \\
x \geq x \\
\text { Bad } \\
x<x\end{array}$ \\
\hline
\end{tabular}


IJMS 26 (1), 99-145 (2019)

\begin{tabular}{|c|c|c|c|c|c|c|}
\hline No & Variable & $\begin{array}{l}\text { Operational } \\
\text { Definition }\end{array}$ & $\begin{array}{l}\text { Measurement } \\
\text { Technique }\end{array}$ & Instrument & Scale & Result \\
\hline \multicolumn{7}{|c|}{ Dependent Variable } \\
\hline & & $\begin{array}{l}\text { meetings, and } \\
\text { developing } \\
\text { teamwork, } \\
\text { also } \\
\text { making some } \\
\text { changes }\end{array}$ & & & & \\
\hline 2 & $\begin{array}{l}\text { Communication } \\
\text { process of nurse } \\
\text { managers }\end{array}$ & $\begin{array}{l}\text { The ability } \\
\text { of nurse } \\
\text { managers in } \\
\text { delivering } \\
\text { information to } \\
\text { subordinates } \\
\text { and receiving } \\
\text { information } \\
\text { from } \\
\text { subordinates }\end{array}$ & $\begin{array}{l}\text { Distribute } \\
\text { questionnaire }\end{array}$ & $\begin{array}{l}\text { Questionnaire } \\
\text { with } \\
\text { statements } \\
\text { and use of } \\
\text { Likertscale }\end{array}$ & Ordinal & $\begin{array}{l}\text { Good } \\
x \geq x \\
\text { Bad } \\
x<x\end{array}$ \\
\hline 3 & $\begin{array}{l}\text { Nurse } \\
\text { managers' } \\
\text { motivation }\end{array}$ & $\begin{array}{l}\text { The ability } \\
\text { of nurse } \\
\text { managers in } \\
\text { motivating } \\
\text { subordinates } \\
\text { positively to } \\
\text { do work }\end{array}$ & $\begin{array}{l}\text { Distribute } \\
\text { questionnaire }\end{array}$ & $\begin{array}{l}\text { Questionnaire } \\
\text { with } 3 \\
\text { statements } \\
\text { and use of } \\
\text { Likert scale }\end{array}$ & Ordinal & $\begin{array}{l}\text { Good } \\
x \geq x \\
\text { Bad } \\
x<x\end{array}$ \\
\hline 4 & $\begin{array}{l}\text { Nurse } \\
\text { managers' } \\
\text { negotiation }\end{array}$ & $\begin{array}{l}\text { The ability } \\
\text { of nurse } \\
\text { managers in } \\
\text { negotiating } \\
\text { agreement } \\
\text { with } \\
\text { subordinates }\end{array}$ & $\begin{array}{l}\text { Distribute } \\
\text { questionnaire }\end{array}$ & $\begin{array}{l}\text { Questionnaire } \\
\text { with } 4 \\
\text { statements } \\
\text { and use of } \\
\text { Likert scale }\end{array}$ & Ordinal & $\begin{array}{l}\text { Good } \\
x \geq x \\
\text { Bad } \\
x<x\end{array}$ \\
\hline 5 & $\begin{array}{l}\text { Nurse } \\
\text { Performance }\end{array}$ & $\begin{array}{l}\text { Workability } \\
\text { is shown by } \\
\text { practitioner } \\
\text { nurses }\end{array}$ & $\begin{array}{l}\text { Distribute } \\
\text { questionnaire }\end{array}$ & $\begin{array}{l}\text { Questionnaire } \\
\text { with } 8 \\
\text { statements } \\
\text { and use of } \\
\text { Likert scale }\end{array}$ & Ordinal & $\begin{array}{l}\text { Good } \\
x \geq x \\
\text { Bad } \\
x<x\end{array}$ \\
\hline
\end{tabular}

The population in this research was practitioner nurses, with 172 nurses at Tgk. Chik Ditiro Sigli Hospital and 159 nurses at Harapan Bunda Banda Aceh Hospital. The total number was 332 practitioner nurses. The reliability of a questionnaire can be ascertained by looking at the alpha value (Riwidikdo, 2010). The decision rule is conducted by comparing the value of $r$ count with $r$ table, whereby if the $r$ count is greater than the $r$ table, it is considered reliable, and if the $r$ count is smaller than the $r$ table, it is not reliable (Ridwan, 2005). The reliability test shows the values of all instruments of the five variables, i.e. $>0.6$, which indicates that the tool is consistent and stable to use. Table 4 shows the result of the instrument reliability test using the Cronbach's alpha model. 
IJMS 26 (1), 99-145 (2019)

Table 4

Cronbach's Alpha Value

\begin{tabular}{lc}
\hline \multicolumn{1}{c}{ Item } & Cronbach's Alpha Value if Item is Deleted \\
\hline & \\
Leadership & .846 \\
Motivation & .641 \\
Communication & .719 \\
Negotiation & .634 \\
Performance & .851 \\
& \\
\hline
\end{tabular}

In this research, the validity test was done by first describing the concept of operational definition, distributing the questionnaire to 25 respondents of the research, and tabulating data. The result of the instrument validity test showed that all instruments of the five variables had a value of less than 0.361 , which meant that all items of the instrument were considered valid.

\section{Bivariate Analysis}

A bivariate analysis was conducted on two variables that were suspected to be correlated (Notoatmodjo, 2012). In this study, the chi-square statistical test with a Confidence Level $(C L)=95$ percent or significance limit ( $\alpha=0.05$ ) was used to test the hypothesis of the relationship between the independent variables and the dependent variable and was processed by a computer. Data of each sub-variable which were inserted into the contingency table were analysed to compare between $\alpha=0.05$ with the following conditions:

1. $\mathrm{H}_{\mathrm{o}}$ is rejected: if the $p$-value $\leq 0.05$, which means that there is a relationship between the dependent and independent variables.

2. $\mathrm{H}_{\mathrm{o}}$ accepted: if the $p$-value $>0.05$, which means that there is no relationship between the dependent and independent variables.

Meanwhile, to know the difference between two groups of interpersonal communication skills of the nurse managers and nurses' performance in Tgk. Chik Ditiro Sigli Hospital and Harapan Bunda Banda Aceh Hospital, this study employed two different tests of the mean (U-test), also called Mann-Whitney U test. The Mann-Whitney $\mathrm{U}$ test is a type of non-parametric statistical test to test the significance 
of the comparative hypothesis of two independent samples when the data is ordinal (Sugiyono, 2013). In this study, the Mann-Whitney U test is used to identify differences in interpersonal communication skills of the nurse managers (in the form of leadership, communication process, motivation, negotiation), and performance of nurses at Tgk. Chik Ditiro Sigli Hospital and Harapan Bunda Banda Aceh Hospital. The two formulas used in the Mann-Whiney $U$ test were utilised to find out which $U$ value was smaller. The smaller $U$ value was used for testing and comparing with $U$ tables. According to Hypothesis Testing Criteria, Ho is accepted when the value of $\mathrm{U}$ is larger than $\mathrm{U}$ table (Sugiyono, 2013). The following are the two formulas for finding U value.

$$
\begin{aligned}
& U_{1}=n_{1} n_{2}+\frac{n_{1}\left(n_{1}+1\right)}{2}-R_{1} \\
& U_{2}=n_{1} n_{2}+\frac{n_{2}\left(n_{2}+1\right)}{2}-R_{2}
\end{aligned}
$$

Where:

$$
\begin{array}{ll}
\mathrm{n}_{1}=\text { Total sample } 1 & \mathrm{U}_{2}=\text { Total Rate } 2 \\
\mathrm{n}_{2}=\text { Total sample } 2 & \mathrm{R}_{1}=\text { Total Rate in Sample } \mathrm{n}_{1} \\
\mathrm{U}_{1}=\text { Total Rate } 1 & \mathrm{R}_{2}=\text { Total Rate in Sample }
\end{array}
$$

\section{Analysis of Results}

Tgk. Chik Ditiro Sigli Hospital is a regional general hospital located at Prof. A. Madjid Ibrahim Street, Pidie, and is owned by the Pidie District Government in Aceh, Indonesia. The demographic data of the respondents (practitioner nurses) and the nurse managers in this study include gender, age, employment, education, rank/class, and place/room. Table 5 shows the results of the data analysis presented in the form of a frequency distribution table.

\section{Demographic Data of Respondents}

Table 5 shows the demographic data of respondents (nurses) at Tgk. Chik Ditiro Sigli Hospital in 2015. A total of 116 respondents $(67.44 \%)$ were female and they represented the most number; 62 respondents (36.1\%) were between 36 and 40 years of age; 61 respondents $(35.5 \%)$ had served less than 5 years; 147 respondents $(85.5 \%)$ had a Diploma III in nursing; 97 respondents (56.4\%) were ranked as non-permanent staff; with the highest number of respondents, equally, i.e. 22 respondents (12.8\%) from the Male Internal Disease Room and Emergency Room 
(IGD); while the lowest number of respondents, 4 (2.3\%) was shared equally between opthalmology and mental polyclinic.

Table 5

Frequency Distribution Based on Demographic Data of Respondents from RSUD Tgk. Chik Ditiro Sigli Hospital in $2015(n=172)$

\begin{tabular}{|c|c|c|c|}
\hline No. & Characteristics & $F$ & $\%$ \\
\hline \multirow[t]{3}{*}{1} & Gender: & & \\
\hline & Male & 56 & 32.56 \\
\hline & Female & 116 & 67.44 \\
\hline \multirow[t]{6}{*}{2} & Age: & & \\
\hline & 20-25 years old & 29 & 16.9 \\
\hline & 26-30 years old & 48 & 27.9 \\
\hline & 31-35 years old & 24 & 13.9 \\
\hline & $36-40$ years old & 62 & 36.1 \\
\hline & $>40$ years old & 9 & 5.2 \\
\hline \multirow[t]{5}{*}{3} & Length of service: & & \\
\hline & $<5$ years & 61 & 35.5 \\
\hline & $5-10$ years & 44 & 25.6 \\
\hline & $11-15$ years & 54 & 31.4 \\
\hline & $>15$ years & 13 & 7.5 \\
\hline \multirow[t]{7}{*}{4} & Education: & & \\
\hline & Nursing School & 5 & 2.9 \\
\hline & Diploma III of Nursing & 147 & 85.5 \\
\hline & Diploma IV of Nursing & 1 & 0.6 \\
\hline & Diploma IV of Midwifery & 1 & 0.6 \\
\hline & Bachelor of Nursing & 16 & 9.3 \\
\hline & Bachelor of Health Science & 2 & 1.2 \\
\hline \multirow[t]{10}{*}{5} & Rank/ Group: & & \\
\hline & Non-permanent staff & 97 & 56.4 \\
\hline & Junior Supervisor & 3 & 1.7 \\
\hline & First Class Junior Supervisor & 1 & 0.6 \\
\hline & Supervisor & 4 & 2.3 \\
\hline & First Class Supervisor & 6 & 3.8 \\
\hline & Junior Superintendent & 36 & 20.9 \\
\hline & First Class Junior & 16 & 9.3 \\
\hline & Superintendent & 6 & 3.5 \\
\hline & First Class Superintendent & 3 & 1.7 \\
\hline
\end{tabular}


IJMS 26 (1), 99-145 (2019)

\begin{tabular}{llcc}
\hline No. Characteristics & $F$ & $\%$ \\
\hline 6 & \multicolumn{1}{c}{ Room: } & 14 & \\
& Pediatry & 17 & 8.1 \\
Male Operating Room & 18 & 9.9 \\
ICU & 22 & 10.5 \\
Emergency Room & 4 & 12.8 \\
Mental & 11 & 2.3 \\
Class I & 10 & 6.4 \\
Perinatology & 4 & 5.8 \\
Opthalmology & 7 & 2.3 \\
Otorhinolaryngology (ENT) & 11 & 4.1 \\
General Operating Room & 22 & 6.4 \\
Male Internal Disease & 16 & 12.8 \\
Female Internal Disease & 16 & 9.3 \\
Neurology & & \\
$\quad$ & 172 & 100 \\
\hline \multicolumn{2}{c}{ Total } & \\
\hline
\end{tabular}

\section{Demographic Data of Nurse Managers}

Table 6 displays the demographic data of nurse managers at Tgk. Chik Ditiro Sigli Hospital in 2015. There were more male nurse managers as 8 respondents $(61.5 \%)$ were male; 6 respondents $(46.15 \%)$ were more than 40 years old; 8 respondents $(61.45 \%)$ had served for more than 15 years; 8 respondents $(61.5 \%)$ were undergraduates majoring in nursing and 7 respondents $(53.8 \%)$ were ranked first-class junior superintendents.

Table 6

Frequency Distribution Based on the Demographic Data of Nurse Managers at Tgk. Chik Ditiro Sigli Hospital in $2015(n=13)$

\begin{tabular}{lllc}
\hline No. & Category & $F$ & $\%$ \\
\hline 1 & Gender: & 8 & \\
& Male & 5 & 61.5 \\
& Female & & 38.5 \\
\multicolumn{1}{c}{2} & Age: & 0 & 0 \\
& 20-25 years & 0 & 0 \\
& 26-30 years & 1 & 7.7 \\
& $31-35$ years & & (continued)
\end{tabular}


IJMS 26 (1), 99-145 (2019)

\begin{tabular}{|c|c|c|c|}
\hline No. & Category & $F$ & $\%$ \\
\hline & $\begin{array}{l}36-40 \text { years } \\
>40 \text { years }\end{array}$ & $\begin{array}{l}6 \\
6\end{array}$ & $\begin{array}{l}46.15 \\
46.15\end{array}$ \\
\hline 3 & $\begin{array}{l}\text { Length of Service: } \\
<5 \text { years } \\
5-10 \text { years } \\
11-15 \text { years } \\
>15 \text { years }\end{array}$ & $\begin{array}{l}0 \\
2 \\
3 \\
8\end{array}$ & $\begin{array}{c}0 \\
15.4 \\
23.1 \\
61.5\end{array}$ \\
\hline 4 & $\begin{array}{l}\text { Education: } \\
\text { School of Nursing } \\
\text { Diploma III of Nursing } \\
\text { Diploma IV of Nursing } \\
\text { Diploma IV of } \\
\text { Midwifery } \\
\text { Undergraduate of } \\
\text { Nursing } \\
\text { Undergraduate of } \\
\text { Health Science }\end{array}$ & $\begin{array}{l}0 \\
3 \\
0 \\
1 \\
8 \\
1\end{array}$ & $\begin{array}{c}0 \\
23.1 \\
0 \\
7.7 \\
61.5 \\
7.7\end{array}$ \\
\hline 5 & $\begin{array}{l}\text { Rank/Group: } \\
\text { Junior Superintendent } \\
\text { First Class Junior } \\
\text { Superintendent } \\
\text { Superintendent } \\
\text { First Class } \\
\text { Superintendent } \\
\text { Administrator }\end{array}$ & $\begin{array}{l}2 \\
7 \\
1 \\
2 \\
1\end{array}$ & $\begin{array}{c}15.4 \\
53.8 \\
7.7 \\
15.4 \\
7.7\end{array}$ \\
\hline & Total & 13 & 100 \\
\hline
\end{tabular}

Table 7

Frequency Distribution Based on the Leadership of Nurse Managers at Tgk. Chik Ditiro Sigli Hospital in $2015(n=172)$

\begin{tabular}{cccc}
\hline No. & Leadership & $F$ & $\%$ \\
\hline 1 & Good & 92 & 53.5 \\
2 & Bad & 80 & 46.5 \\
\hline & Total & 172 & 100 \\
\hline
\end{tabular}

\section{Leadership of Nurse Managers}

Table 7 illustrates the leadership of nurse managers at Tgk. Chik Ditiro Sigli Hospital in 2015. 92 (53.5\%) respondents fell under the good category. 
IJMS 26 (1), 99-145 (2019)

\section{Communication Process of Nurse Managers}

Table 8 illustrates the communication process between nurses and nurse managers at Tgk. Chik Ditiro Sigli Hospital in 2015. 96 (55.8\%) respondents fell under the bad category in terms of the communication process between nurse managers and nurses.

Table 8

Frequency Distribution Based on the Communication Process of Nurse Managers at Tgk. Chik Ditiro Sigli Hospital in 2015 ( $n=172)$

\begin{tabular}{cccc}
\hline No. & Communication Process & $\mathrm{f}$ & $\%$ \\
\hline 1 & Good & 76 & 44.2 \\
2 & Bad & 96 & 55.8 \\
\hline & Total & 172 & 100 \\
\hline
\end{tabular}

\section{Motivation of Nurse Managers}

Table 9 illustrates that the ability of nurse managers motivation in RSUD Tgk. Chik Ditiro Sigli by 2015, the majority is in a good category as many as $98(57.0 \%)$ of respondents, and bad category as many as 74 $(43.0 \%)$ of respondents.

Table 9

Frequency Distribution Based on the Motivation of Nurse Managers at Tgk. Chik Ditiro Sigli Hospital in $2015(n=172)$

\begin{tabular}{cccc}
\hline No. & Motivation & $f$ & $\%$ \\
\hline 1 & Good & 98 & 57.0 \\
2 & Bad & 74 & 43.0 \\
\hline & Total & 172 & 100 \\
\hline
\end{tabular}

\section{Negotiation of Nurse Managers}

Table 10 illustrates the negotiation ability of the nurse managers at Tgk. Chik Ditiro Sigli Hospital in 2015. 97 (56.4\%) respondents fell 
under the bad category while the rest was under the good category with $75(43,6 \%)$ respondents.

Table 10

Frequency Distribution Based on the Negotiation of Nurse Managers at Tgk. Chik Ditiro Sigli Hospital in $2015(n=172)$

\begin{tabular}{cccc}
\hline No. & Negotiation & $f$ & $\%$ \\
\hline 1 & Good & 75 & 43.6 \\
2 & Bad & 97 & 56.4 \\
\hline & Total & 172 & 100 \\
\hline
\end{tabular}

The Relationship Between the Leadership of Nurse Managers and Nursing Performance

Table 11

The Relationship between the Leadership of Nurse Managers and Nursing Performance at Tgk. Chik Ditiro Sigli Hospital in 2015 ( $n=172)$

Table 11 shows the relationship between the leadership of nurse managers and the performance of nurses at Tgk. Chik Ditiro in 2015 based on 172 respondents. A total of 92 (53.5\%) respondents stated that they had nurse managers with good leadership, while 80 $(46.5 \%)$ respondents argued that they had nurse managers with bad leadership. Of the respondents who claimed to have had good nurse managers, $58(76.3 \%)$ of them showed good performance, while 34 $(35.4 \%)$ respondents showed poor performance.

Meanwhile, among the respondents who claimed to have had nurse managers with bad leadership, 18 (23.7\%) respondents displayed good performance, while $62(64.6 \%)$ of them showed poor performance. Data analysis to test the hypothesis of research on the relationship of the nurse managers' leadership with the performance of nurses at Tgk. Chik Ditiro Sigli Hospital in 2015 was conducted using Chisquare. The p-value analysis is $0.000(<0.05)$, so $\mathrm{H}_{\mathrm{o}}$ is rejected, and $\mathrm{H}_{\mathrm{a}}$ is accepted, which means that there is a significant relationship between nurse managers' leadership and nurses' performance. 
IJMS 26 (1), 99-145 (2019)

\begin{tabular}{cccccccc}
\hline \multirow{2}{*}{ No. } & \multirow{2}{*}{$\begin{array}{c}\text { Nursing } \\
\text { Performance }\end{array}$} & \multicolumn{4}{c}{ Leadership } & \multirow{2}{*}{ Total } & $\%$ \\
\cline { 3 - 6 } & & \multicolumn{2}{c}{ Good } & \multicolumn{2}{c}{ Bad } & & \\
& & F & $\%$ & F & $\%$ & & \\
\hline 1 & Good & 58 & 76.3 & 18 & 23.7 & 76 & 100 \\
2 & Bad & 34 & 35.4 & 62 & 64.6 & 96 & 100 \\
\hline & Total & 92 & 53.5 & 80 & 46.5 & 172 & 100 \\
\hline
\end{tabular}

Table 12

Chi-Square Tests

\begin{tabular}{|c|c|c|c|c|c|}
\hline & Value & Df & $\begin{array}{l}\text { Asymp. } \\
\text { Sig. } \\
\text { (2-sided) }\end{array}$ & $\begin{array}{l}\text { Exact Sig. } \\
\text { (2-sided) }\end{array}$ & $\begin{array}{l}\text { Exact Sig. } \\
\text { (1-sided) }\end{array}$ \\
\hline $\begin{array}{l}\text { Pearson } \\
\text { Chi-Square }\end{array}$ & $28,521^{\mathrm{a}}$ & 1 & ,000 & & \\
\hline $\begin{array}{l}\text { Continuity } \\
\text { Correction }^{\mathrm{b}}\end{array}$ & 26,901 & 1 & ,000 & & \\
\hline Likelihood Ratio & 29,600 & 1 & ,000 & & \\
\hline Fisher's Exact Test & & & & ,000 & , 000 \\
\hline $\begin{array}{l}\text { Linear-by-Linear } \\
\text { Association }\end{array}$ & 28,355 & 1 & ,000 & & \\
\hline $\mathrm{N}$ of Valid Cases & 172 & & & & \\
\hline
\end{tabular}

1. 0 cells $(, 0 \%)$ have expected count less than 5 . The minimum expected count is 5,35 .

2. Computed only for a $2 \times 2$ table

\section{The Relationship between the Communication Process of Nurse Managers and Nursing Performance}

Table 13 illustrates the relationship between the communication process of nurse managers and nurses' performance at Tgk. Chik Ditiro Sigli Hospital in 2015 based on 172 respondents. About 76 $(44.2 \%)$ respondents claimed that they had nurse managers with good communication process while as many as 96 (55.8\%) respondents argued that they had nurse managers with bad communication 
process. Among the respondents who argued that they had nurse managers with good communication process, 55 (72.4\%) of them showed good performance, while 21 (21.9\%) respondents had poor performance. Whereas for respondents who claimed to have had nurse managers with poor communication process, only $21(27.6 \%)$ respondents showed good performance, while $75(78.1 \%)$ respondents had poor performance.

Data analysis to test the research hypothesis on the relationship between the communication process of nurse managers and the performance of nurses at Tgk. Chik Ditiro Sigli Hospital in 2015 was conducted using Chi-Square. The p-value analysis is $0.000(<0.05)$, so $\mathrm{H}_{\mathrm{o}}$ is rejected, and $\mathrm{H}_{\mathrm{a}}$ is accepted, which means that there is a significant relationship between the communication process of the nurse managers and the nurses' performance.

Table 13

The Relationship between the Communication Process of Nurse Managers and Nursing Performance at Tgk. Chik Ditiro Sigli Hospital in 2015 ( $n=172)$

\begin{tabular}{cccccccc}
\hline \multirow{2}{*}{ No. } & Nursing & \multicolumn{2}{c}{ Communication Process } & \multirow{2}{*}{ Total } & $\%$ \\
\cline { 3 - 6 } & & \multicolumn{2}{c}{ Good } & \multicolumn{2}{c}{ Bad } & & \\
\cline { 3 - 6 } & $F$ & $\%$ & $f$ & $\%$ & & \\
\hline 1 & Gorformance & 55 & 72.4 & 21 & 27.6 & 76 & 100 \\
2 & Bad & 21 & 21.9 & 75 & 78.1 & 96 & 100 \\
\hline & Total & 76 & 44.2 & 96 & 55.8 & 172 & 100 \\
\hline
\end{tabular}

Table 14

Chi-Square Tests

\begin{tabular}{lccccc}
\hline & Value & Df & $\begin{array}{c}\text { Asymp. Sig. } \\
\text { (2-sided) }\end{array}$ & $\begin{array}{c}\text { Exact Sig. } \\
\text { (2-sided) }\end{array}$ & $\begin{array}{c}\text { Exact Sig. } \\
\text { (1-sided) }\end{array}$ \\
\hline $\begin{array}{l}\text { Pearson } \\
\text { Chi-Square }\end{array}$ & $43,853^{\text {a }}$ & 1 &, 000 & & \\
\hline
\end{tabular}

(continued) 
IJMS 26 (1), 99-145 (2019)

\begin{tabular}{lccccc}
\hline & Value & Df & $\begin{array}{c}\text { Asymp. Sig. } \\
\text { (2-sided })\end{array}$ & $\begin{array}{r}\text { Exact Sig. } \\
\text { (2-sided) }\end{array}$ & $\begin{array}{r}\text { Exact Sig. } \\
\text { (1-sided) }\end{array}$ \\
\hline $\begin{array}{l}\text { Continuity } \\
\text { Correction }\end{array}$ & 41,829 & 1 &, 000 & & \\
$\begin{array}{l}\text { Likelihood Ratio } \\
\text { Fisher's Exact Test }\end{array}$ & 45,655 & 1 &, 000 & &, 000 \\
$\begin{array}{l}\text { Linear-by-Linear } \\
\text { Association }\end{array}$ & 43,598 & 1 &, 000 & & \\
N of Valid Cases & 172 & & & & \\
\hline
\end{tabular}

1. 0 cells $(, 0 \%)$ have expected count less than 5 . The minimum expected count is 3,58 .

2. Computed only for a $2 \times 2$ table

The Relationship between the Motivation of Nurse Managers and Nursing Performance

Table 15 shows the relationship between the motivation of nurse managers and nurses' performance at Tgk. Chik Ditiro Sigli Hospital in 2015 based on 172 respondents. It was observed that 98 (57\%) respondents claimed to have had nurse managers with good motivation ability, while as many as $74(43 \%)$ respondents had nurse managers with bad motivation ability. Among the respondents who claimed to have had nurse managers with good motivation ability, $58(76.3 \%)$ of them showed good performance while $40(41.7 \%)$ respondents had poor performance. For respondents who claimed to have had nurse managers with poor motivation ability, 18 (23.7\%) respondents showed good performance while 56 (58.3\%) of them had poor performance. Data analysis to test the research hypothesis about the relationship between the motivation of nurse managers and the performance of nurses at Tgk. Chik Ditiro Sigli Hospital in 2015 was conducted using Chi-Square. The p-value analysis is $0.000(<0.05)$, so $\mathrm{H}_{\mathrm{o}}$ is rejected, which means that there is a correlation between the motivation of nurse managers and nursing performance. 
IJMS 26 (1), 99-145 (2019)

\section{Table 15}

The Relationship between the Motivation of Nurse Managers and Nursing Performance at Tgk. Chik Ditiro Sigli Hospital in 2015 (n=172)

\begin{tabular}{|c|c|c|c|c|c|c|c|}
\hline \multirow[t]{3}{*}{ No. } & \multirow{3}{*}{$\begin{array}{c}\text { Nursing } \\
\text { Performance }\end{array}$} & \multicolumn{4}{|c|}{ Motivation } & \multirow[t]{3}{*}{ Total } & \multirow[t]{3}{*}{$\%$} \\
\hline & & \multicolumn{2}{|c|}{ Good } & \multicolumn{2}{|c|}{ Bad } & & \\
\hline & & $f$ & $\%$ & $f$ & $\%$ & & \\
\hline 1 & Good & 58 & 76.3 & 18 & 23.7 & 76 & 100 \\
\hline \multirow[t]{2}{*}{2} & Bad & 40 & 41.7 & 56 & 58.3 & 96 & 100 \\
\hline & Total & 98 & 57.0 & 74 & 43.0 & 172 & 100 \\
\hline
\end{tabular}

Table 16

Chi-Square Tests.

\begin{tabular}{lccccc}
\hline & Value & Df & $\begin{array}{c}\text { Asymp. } \\
\text { Sig. } \\
\text { (2-sided) }\end{array}$ & $\begin{array}{c}\text { Exact } \\
\text { Sig. } \\
\text { (2-sided) }\end{array}$ & $\begin{array}{c}\text { Exact } \\
\text { Sig. } \\
\text { (1-sided) }\end{array}$ \\
\hline $\begin{array}{l}\text { Pearson } \\
\text { Chi-Square }\end{array}$ & $20,775^{\mathrm{a}}$ & 1 &, 000 & & \\
$\begin{array}{l}\text { Continuity } \\
\text { Correction }\end{array}$ & 19,386 & 1 &, 000 & & \\
$\begin{array}{l}\text { Likelihood } \\
\text { Ratio }\end{array}$ & 21,471 & 1 &, 000 & & \\
$\begin{array}{l}\text { Fisher's } \\
\text { Exact Test }\end{array}$ & & & & & \\
$\begin{array}{l}\text { Lin ear- } \\
\text { by-Linear } \\
\text { Association }\end{array}$ & 20,654 & 1 &, 000 & \\
$\begin{array}{l}\text { N of Valid } \\
\text { Cases }\end{array}$ & 172 & & & & \\
\hline
\end{tabular}

1. 0 cells $(, 0 \%)$ have expected count less than 5 . The minimum expected count is 32,70 .

2. Computed only for a $2 \times 2$ table 
Table 17 shows the relationship between the negotiation ability of nurse managers and nursing performance at Tgk. Chik Ditiro Sigli Hospital in 2015 based on 172 respondents. It was observed that 75 (43.6\%) respondents claimed to have had nurse managers with good negotiation ability, and $97(56.4 \%)$ respondents had nurse managers with bad negotiation skills. Among the respondents who claimed to have had nurse managers with good negotiation ability, 61 (80.3\%) respondents showed good performance, while 14 (14.6\%) respondents had poor performance. Meanwhile, respondents who stated that they had nurse managers with poor negotiation ability, $15(19.7 \%)$ respondents showed good performance, while $82(85.4 \%)$ respondents had poor performance. Data analysis to test the research hypothesis on the relationship between the negotiation of nurse managers and the performance of nurses at Tgk. Chik Ditiro Sigli Hospital in 2015 was conducted using Chi-Square. The p-value analysis is $0.000(<0.05), \mathrm{so}_{\mathrm{o}}$ is rejected, and $\mathrm{H}_{\mathrm{a}}$ is accepted which means that there is a significant relationship between the negotiation ability of nurse managers and the performance of the nurses.

Table 17

The Relationship between the Negotiation of Nurse Managers and Nursing Performance at Tgk. Chik Ditiro Sigli Hospital in $2015(n=172)$

\begin{tabular}{|c|c|c|c|c|c|c|c|}
\hline \multirow[t]{3}{*}{ No. } & \multirow{3}{*}{$\begin{array}{c}\text { Nursing } \\
\text { Performance }\end{array}$} & \multicolumn{4}{|c|}{ Negotiation } & \multirow[t]{3}{*}{ Total } & \multirow[t]{3}{*}{$\%$} \\
\hline & & \multicolumn{2}{|c|}{ Good } & \multicolumn{2}{|c|}{ Bad } & & \\
\hline & & $F$ & $\%$ & $f$ & $\%$ & & \\
\hline 1 & Good & 61 & 80.3 & 15 & 19.7 & 76 & 100 \\
\hline \multirow[t]{2}{*}{2} & Bad & 14 & 14.6 & 82 & 85.4 & 96 & 100 \\
\hline & Total & 75 & 43.6 & 97 & 56.4 & 172 & 100 \\
\hline
\end{tabular}

Table 18

Chi-Square Tests

\begin{tabular}{|c|c|c|c|c|c|}
\hline & Value & Df & $\begin{array}{c}\text { Asymp. } \\
\text { Sig. } \\
\text { (2-sided) }\end{array}$ & $\begin{array}{c}\text { Exact } \\
\text { Sig. } \\
\text { (2-sided) }\end{array}$ & $\begin{array}{c}\text { Exact } \\
\text { Sig. } \\
\text { (1-sided) }\end{array}$ \\
\hline $\begin{array}{l}\text { Pearson Chi- } \\
\text { Square }\end{array}$ & $74,412^{a}$ & 1 & ,000 & & \\
\hline
\end{tabular}

(continued) 
IJMS 26 (1), 99-145 (2019)

\begin{tabular}{lccccc}
\hline & Value & Df & $\begin{array}{c}\text { Asymp. } \\
\text { Sig. } \\
(2 \text {-sided })\end{array}$ & $\begin{array}{c}\text { Exact } \\
\text { Sig. } \\
(2 \text {-sided })\end{array}$ & $\begin{array}{c}\text { Exact Sig. } \\
\text { (1-sided })\end{array}$ \\
\hline $\begin{array}{l}\text { Continuity } \\
\text { Correction }\end{array}$ & 71,765 & 1 &, 000 & & \\
$\begin{array}{l}\text { Likelihood } \\
\text { Ratio }\end{array}$ & 80,358 & 1 &, 000 & &, 000 \\
$\begin{array}{l}\text { Fisher's } \\
\text { Exact Test }\end{array}$ & & & & & \\
$\begin{array}{l}\text { Linear- } \\
\text { by-Linear }\end{array}$ & 73,980 & 1 &, 000 & & \\
Association & & & & & \\
$\begin{array}{l}\text { N of Valid } \\
\text { Cases }\end{array}$ & 172 & & & & \\
\hline
\end{tabular}

1. 0 cells $(, 0 \%)$ have expected count less than 5 . The minimum expected count is 33,14 .

2. Computed only for a $2 \times 2$ table

\section{Profile of Harapan Bunda Banda Aceh Hospital}

Harapan Bunda Banda Aceh Hospital is a private hospital located at Jl. T. Umar no. 181-211 Banda Aceh. Harapan Bunda Banda Aceh Hospital was founded by Dr. Zainal Bakri TA, on December 25, 1991. The demographic data of the respondents and the nurse managers in this study include gender, age, employment, education, and place/ room. Table 4.15 shows the distribution of the demographic data of the respondents.

The demographic data of respondents at Harapan Bunda Banda Aceh Hospital in 2015 is displayed in Table 19. The highest number in the gender category were women with 146 (91.8\%) respondents; 83 (51.6\%) respondents were $20-25$ years old; 83 (52.2\%) respondents had served more than 5 years; 153 (96.2\%) respondents had a Diploma III in nursing; the rooms with the most number of respondents came from the ICU/ ICCU and Ward 3 with 18 (11.3\%) and 17 (10.7\%) respondents respectively, and the lowest number of respondents was the VIP room with 5 (3.1\%) respondents. 
IJMS 26 (1), 99-145 (2019)

\section{Demographic Data of Respondents}

Table 19

Frequency Distribution based on the Demographic Data of Respondents at Harapan Bunda Banda Aceh Hospital in $2015(n=172)$

\begin{tabular}{|c|c|c|c|}
\hline No & Category & $F$ & $\%$ \\
\hline 1 & $\begin{array}{l}\text { Gender: } \\
\text { Male } \\
\text { Female }\end{array}$ & $\begin{array}{c}13 \\
146\end{array}$ & $\begin{array}{c}8,2 \\
91,8\end{array}$ \\
\hline 2 & $\begin{array}{l}\text { Age: } \\
20-25 \text { years } \\
26-30 \text { years } \\
31-35 \text { years } \\
36-40 \text { years } \\
>40 \text { years }\end{array}$ & $\begin{array}{c}83 \\
57 \\
14 \\
5 \\
-\end{array}$ & $\begin{array}{c}52.2 \\
35.8 \\
8.8 \\
3.1 \\
-\end{array}$ \\
\hline 3 & $\begin{array}{l}\text { Length of Service: } \\
<5 \text { years } \\
5-10 \text { years } \\
11-15 \text { years } \\
>15 \text { years }\end{array}$ & $\begin{array}{c}83 \\
55 \\
21 \\
-\end{array}$ & $\begin{array}{c}52.2 \\
34.6 \\
13.2 \\
-\end{array}$ \\
\hline 4 & $\begin{array}{l}\text { Education: } \\
\text { School of Nursing } \\
\text { Diploma III of Nursing } \\
\text { Diploma IV of Nursing } \\
\text { Diploma IV of Midwifery } \\
\text { Undergraduate of Nursing } \\
\text { Undergraduate of Health } \\
\text { Science }\end{array}$ & $\begin{array}{c}- \\
153 \\
1 \\
- \\
5 \\
-\end{array}$ & $\begin{array}{c}- \\
96.2 \\
0.6 \\
- \\
3.2 \\
-\end{array}$ \\
\hline 5 & $\begin{array}{l}\text { Room: } \\
\text { Super VIP } \\
\text { VIP Level II } \\
\text { VIP Level II } \\
\text { VIP Level I } \\
\text { VIP Level IV } \\
\text { Ward } 3 \\
\text { Ward } 4 \\
\text { Emergency Room } \\
\text { ICU/ICCU } \\
\text { NICU } \\
\text { Male Internal Disease } \\
\text { Fruit-named Room } \\
\text { Stone-named Room } \\
\text { Operating Room } \\
\text { New L3 Room } \\
\text { Dal Room }\end{array}$ & $\begin{array}{c}12 \\
9 \\
10 \\
10 \\
5 \\
17 \\
6 \\
14 \\
18 \\
8 \\
6 \\
7 \\
10 \\
9 \\
10 \\
8\end{array}$ & $\begin{array}{c}7.5 \\
5.7 \\
6.3 \\
6.3 \\
3.1 \\
10.7 \\
3.8 \\
8.8 \\
11.3 \\
5.0 \\
3.8 \\
4.4 \\
6.3 \\
5.7 \\
6.3 \\
5.0\end{array}$ \\
\hline & Total & 159 & 100 \\
\hline
\end{tabular}


IJMS 26 (1), 99-145 (2019)

\section{Demographic Data of Nurse Managers}

Table 20 shows the demographic data of nurse managers at Harapan Bunda Banda Aceh Hospital in 2015. Based on gender, all nurse managers here were women with a total of $16(100 \%)$ respondents; 11 $(68.7 \%)$ respondents were $31-40$ years old. There was only one $(6.3 \%)$ respondent each for the youngest age category i.e. between 20 to 25 years old and more than 40 years old category; 8 (50\%) respondents had served for 5-10 years; 15 (93.7\%) respondents had a Diploma III in nursing while only one (6.3\%) respondent had an undergraduate degree in nursing.

Table 20

Frequency Distribution based on the Demographic Data of Nurse Managers at Harapan Bunda Banda Aceh Hospital in $2015(n=16)$

\begin{tabular}{|c|c|c|c|}
\hline No. & Category & $f$ & $\%$ \\
\hline 1 & $\begin{array}{l}\text { Gender: } \\
\text { Male } \\
\text { Female }\end{array}$ & $\begin{array}{c}0 \\
16\end{array}$ & $\begin{array}{c}0 \\
100\end{array}$ \\
\hline 2 & $\begin{array}{l}\text { Age: } \\
\text { 20-25 years } \\
26-30 \text { years } \\
31-35 \text { years } \\
36-40 \text { years } \\
>40 \text { years }\end{array}$ & $\begin{array}{c}1 \\
3 \\
11 \\
1\end{array}$ & $\begin{array}{c}6,3 \\
18,7 \\
68,7 \\
6,3\end{array}$ \\
\hline 3 & $\begin{array}{l}\text { Length of service: } \\
<5 \text { years } \\
5-10 \text { years } \\
11-15 \text { years } \\
>15 \text { years }\end{array}$ & $\begin{array}{l}2 \\
8 \\
6 \\
0\end{array}$ & $\begin{array}{c}12,5 \\
50,0 \\
37,5 \\
0\end{array}$ \\
\hline 4 & $\begin{array}{l}\text { Education: } \\
\text { Diploma III of } \\
\text { Nursing } \\
\text { Diploma IV of } \\
\text { Nursing } \\
\text { Diploma IV of } \\
\text { Midwifery } \\
\text { Bachelor of Nursing }\end{array}$ & $\begin{array}{c}15 \\
0 \\
0 \\
1\end{array}$ & $\begin{array}{c}93,7 \\
0 \\
0 \\
6,3\end{array}$ \\
\hline & Total & 16 & 100 \\
\hline
\end{tabular}


IJMS 26 (1), 99-145 (2019)

\section{Leadership of Nurse Managers}

Table 21 illustrates that the leadership of nurse managers at Harapan Bunda Banda Aceh Hospital in 2015 falls largely under the good category, with 131 (82.4\%) respondents.

Table 21

Frequency Distribution based on the Leadership of Nurse Managers at Harapan Bunda Banda Aceh Hospital in 2015 (n=159).

\begin{tabular}{cccc}
\hline No. & Leadership & $f$ & $\%$ \\
\hline 1 & Good & 131 & 82.4 \\
2 & Bad & 28 & 17.6 \\
\hline & Total & 159 & 100 \\
\hline
\end{tabular}

\section{Communication Process of Nurse Managers}

Table 22 illustrates that the communication process between nurse managers and practitioner nurses at Harapan Bunda Banda Aceh Hospital in 2015 falls largely under the good category with 147 (92.5\%) respondents.

Table 22

Frequency Distribution Based on the Communication Process of Nurse Managers at Harapan Bunda Banda Aceh Hospital in $2015(n=159)$.

\begin{tabular}{cccc}
\hline No. & Communication Process & $f$ & $\%$ \\
\hline 1 & Good & 147 & 92.5 \\
2 & Bad & 12 & 7.5 \\
\hline & Total & 159 & 100 \\
\hline
\end{tabular}

\section{Motivation of Nurse Managers}

Table 23 illustrates that the motivation of the nurse managers at Harapan Bunda Banda Aceh Hospital in 2015 is in the good category, with 99 (63.2\%) respondents. 
IJMS 26 (1), 99-145 (2019)

Table 23

Frequency Distribution based on the Motivation of Nurse Managers at Harapan Bunda Banda Aceh Hospital in $2015(n=159)$

\begin{tabular}{cccc}
\hline No. & Motivation & $f$ & $\%$ \\
\hline 1 & Good & 99 & 62.3 \\
2 & Bad & 60 & 37.7 \\
\hline & Total & 159 & 100 \\
\hline
\end{tabular}

\section{Negotiation of Nurse Managers}

Table 24 illustrates the negotiation of nurse managers at Harapan Bunda Banda Aceh Hospital in 2015 falls largely under the good category, with 99 (63.2\%) respondents.

Table 24

Frequency Distribution Based on the Negotiation of Nurse Managers at Harapan Bunda Banda Aceh Hospital in 2015 (N = 159)

\begin{tabular}{lccc}
\hline No. & Negotiation & $f$ & $\%$ \\
\hline 1 & Good & 143 & 89.9 \\
2 & Bad & 16 & 10.1 \\
\hline & Total & 159 & 100 \\
\hline
\end{tabular}

Source: Primary Data (Processed in January 2015)

Table 25 shows the relationship between the leadership of the nurse managers and nursing performance at Harapan Bunda Banda Aceh Hospital in 2015 based on 159 respondents. A total of $131(82.4 \%)$ respondents claimed to have had nurse managers with good leadership, while 28 (17.6\%) respondents had nurse managers with bad leadership. Among the respondents who claimed to have had nurse managers with good leadership, $110(84 \%)$ respondents showed good performance, while $21(16 \%)$ respondents had poor performance. 
Meanwhile, among the respondents who claimed to have had nurse managers with poor leadership, 15 (53.6\%) respondents were found to show good performance, while $13(46.4 \%)$ respondents had poor performance. Data analysis to test the research hypothesis about the relationship between nurse managers' leadership and nurse performance at Harapan Bunda Banda Aceh Hospital in 2015 was conducted using Chi-Square test. The p-value analysis is $0.000(<0.05)$, so $\mathrm{H}_{\mathrm{o}}$ is rejected, and there is significant relationship between nurse managers' leadership and nursing performance.

Table 25

The Relationship between the Leadership of Nurse Managers and Nursing Performance at Harapan Bunda Banda Aceh Hospital in 2015 (n=159)

\begin{tabular}{|c|c|c|c|c|c|c|c|}
\hline \multirow{3}{*}{ No. } & \multirow{3}{*}{$\begin{array}{c}\text { Nurse } \\
\text { Performance }\end{array}$} & \multicolumn{4}{|c|}{ Leadership } & \multirow{3}{*}{ Total } & \multirow{3}{*}{$\%$} \\
\hline & & \multicolumn{2}{|c|}{ Good } & \multicolumn{2}{|c|}{ Bad } & & \\
\hline & & $F$ & $\%$ & $f$ & $\%$ & & \\
\hline 1 & Good & 110 & 84 & 15 & 53.6 & 76 & 100 \\
\hline \multirow[t]{2}{*}{2} & Bad & 21 & 16 & 13 & 46.4 & 96 & 100 \\
\hline & Total & 131 & 82.4 & 28 & 17.6 & 159 & 100 \\
\hline
\end{tabular}

Table 26

Chi-Square Tests

\begin{tabular}{lccccc}
\hline \multicolumn{5}{c}{ Chi-Square Tests } \\
\hline & Value & Df & $\begin{array}{c}\text { Asymp. } \\
\text { Sig. } \\
\text { (2-sided) }\end{array}$ & $\begin{array}{c}\text { Exact Sig. } \\
\text { (2-sided) }\end{array}$ & $\begin{array}{c}\text { Exact Sig. } \\
\text { (1-sided) }\end{array}$ \\
\hline Pearson Chi-Square & $12,680^{\mathrm{a}}$ & 1 &, 000 & \\
Continuity $_{\text {Correction }}^{\mathrm{b}}$ & 10,937 & 1 &, 001 & \\
Likelihood Ratio $^{\mathrm{n}}$ & 11,041 & 1 &, 001 & \\
\hline
\end{tabular}


IJMS 26 (1), 99-145 (2019)

\begin{tabular}{|c|c|c|c|c|c|}
\hline \multicolumn{6}{|c|}{ Chi-Square Tests } \\
\hline & Value & Df & $\begin{array}{l}\text { Asymp. } \\
\text { Sig. } \\
\text { (2-sided) }\end{array}$ & $\begin{array}{l}\text { Exact Sig. } \\
\text { (2-sided) }\end{array}$ & $\begin{array}{l}\text { Exact Sig. } \\
\text { (1-sided) }\end{array}$ \\
\hline Fisher's Exact Test & & & & ,001 & ,001 \\
\hline $\begin{array}{l}\text { Linear-by-Linear } \\
\text { Association }\end{array}$ & 12,601 & 1 & ,000 & & \\
\hline $\mathrm{N}$ of Valid Cases & 159 & & & & \\
\hline
\end{tabular}

1. 0 cells $(, 0 \%)$

have expected

count less than

5. The minimum

expected

count is 32,70 .

2. Computed only

for a $2 \times 2$ table

\section{The Relationship between the Communication Process of Nurse Managers and Nursing Performance}

Table 27 shows the relationship between the leadership of the nurse managers and nursing performance at Harapan Bunda Banda Aceh Hospital in 2015 based on 159 respondents. It was found that 147 $(92.4 \%)$ respondents claimed to have had nurse managers with good communication process, while $12(7.6 \%)$ respondents claimed to have had nurse managers with bad communication process. Among the respondents who claimed to have had nurse managers with good communication process, 122 (83\%) respondents showed good performance, while $26(17 \%)$ respondents had poor performance. Whereas respondents who claimed to have had nurse managers with poor communication process, $3(25 \%)$ respondents were observed to show good performance, while $9(75 \%)$ respondents had poor performance. Data analysis to test the research hypothesis on the relationship of the communication process of nurse managers with nursing performance at Harapan Bunda Banda Aceh Hospital in 2015 was conducted using Chi-Square test. The p-value analysis is 0.000 $(<0.05)$, so $\mathrm{H}_{\mathrm{o}}$ is rejected, and $\mathrm{H}_{\mathrm{a}}$ is accepted, which means there is a relationship between the communications process of nurse managers with the performance of nurses. 
IJMS 26 (1), 99-145 (2019)

Table 27

The Relationship between the Communication Process of the Nurse Managers and Nursing performance at Harapan Bunda Banda Aceh Hospital in 2015 $(n=159)$

\begin{tabular}{|c|c|c|c|c|c|c|c|}
\hline \multirow{3}{*}{ No. } & \multirow{3}{*}{$\begin{array}{c}\text { Nursing } \\
\text { Performance }\end{array}$} & \multicolumn{4}{|c|}{ Communication Process } & \multirow{3}{*}{ Total } & \multirow{3}{*}{$\%$} \\
\hline & & \multicolumn{2}{|c|}{ Good } & \multicolumn{2}{|c|}{ Bad } & & \\
\hline & & $f$ & $\%$ & $f$ & $\%$ & & \\
\hline 1 & Good & 122 & 83 & 3 & 25 & 125 & 100 \\
\hline 2 & Bad & 26 & 17 & 9 & 75 & 34 & 100 \\
\hline & Total & 147 & 92,4 & 12 & 7,6 & 159 & 100 \\
\hline
\end{tabular}

Table 28

Chi-Square Tests

\begin{tabular}{lccccc}
\hline \multicolumn{5}{c}{ Chi-Square Tests } \\
& Value & Df & $\begin{array}{c}\text { Asymp. } \\
\text { Sig. } \\
\text { (2-sided) }\end{array}$ & $\begin{array}{c}\text { Exact } \\
\text { Sig. } \\
\text { (2-sided) }\end{array}$ & $\begin{array}{c}\text { Exact Sig. } \\
\text { (1-sided) }\end{array}$ \\
\hline $\begin{array}{l}\text { Pearson Chi- } \\
\text { Square }\end{array}$ & $22,195^{\mathrm{a}}$ & 1 &, 000 & & \\
$\begin{array}{l}\text { Continuity } \\
\text { Correction }\end{array}$ & 18,880 & 1 &, 000 & & \\
$\begin{array}{l}\text { Likelihood Ratio } \\
\text { Fisher's Exact Test }\end{array}$ & 17,482 & 1 &, 000 & \\
$\begin{array}{l}\text { Linear-by-Linear } \\
\text { Association }\end{array}$ & 22,056 & 1 &, 000 & & \\
N of Valid Cases & 159 & & & & \\
\hline
\end{tabular}

1. 0 cells $(, 0 \%)$ have expected count less than 5 . The minimum expected count is 32,70 .

2. Computed only for a $2 \times 2$ table 
IJMS 26 (1), 99-145 (2019)

Table 29

The Relationship between the Motivation of Nurse Managers and Nursing Performance at Harapan Bunda Banda Aceh Hospital in 2015 (n=159)

\begin{tabular}{cccccccc}
\hline \multirow{2}{*}{ No. } & \multirow{2}{*}{$\begin{array}{c}\text { Nursing } \\
\text { Performance }\end{array}$} & \multicolumn{4}{c}{ Motivation } & \multirow{2}{*}{ Total } & $\%$ \\
\cline { 3 - 6 } & & \multicolumn{2}{c}{ Good } & \multicolumn{2}{c}{ Bad } & & \\
\cline { 3 - 6 } & & $f$ & $\%$ & $f$ & $\%$ & & 100 \\
\hline 1 & Good & 85 & 85,9 & 40 & 66,7 & 125 & 100 \\
2 & Bad & 14 & 14,1 & 20 & 33,3 & 34 & 100 \\
\hline
\end{tabular}

Source: Primary Data (Processed in January 2015)

Table 29 shows the relationship between the motivation of nurse managers and nursing performance at Harapan Bunda Banda Aceh Hospital in 2015 based on 159 respondents. It was observed that $99(62.3 \%)$ respondents claimed to have had nurse managers with good motivation ability, while $60(27.7 \%)$ respondents had nurse managers with bad motivation. Among the respondents who claimed to have had nurse managers with good motivation ability, $85(85.9 \%)$ respondents showed good performance, while $14(14.1 \%)$ respondents had poor performance. For respondents who claimed to have had nurse managers with poor motivation ability, 40 (66.7\%) respondents showed good performance, while $20(33.3 \%)$ respondents had poor performance. Data analysis to test the research hypothesis on the relationship between the motivation of nurse managers and nursing performance at Harapan Bunda Banda Aceh in 2015 was conducted using Chi-Square test. The p-value analysis is $(0.000<0.05)$, so $\mathrm{H}_{\mathrm{o}}$ is rejected, and $\mathrm{H}_{\mathrm{a}}$ is accepted, which means that there is a relationship between the motivation skills of nurse managers and the performance of nurses.

Table 31 shows the relationship between the negotiation of nurse managers and nursing performance at Harapan Bunda Banda Aceh in 2015 based on 159 respondents. It was found that 143 (89.9\%) respondents stated that they had nurse managers with good 
IJMS 26 (1), 99-145 (2019)

Table 30

Chi-Square Tests

\begin{tabular}{lccccc}
\hline \multicolumn{5}{c}{ Chi-Square Tests } \\
\hline & Value & Df & $\begin{array}{c}\text { Asymp. } \\
\text { Sig. } \\
\text { (2-sided) }\end{array}$ & $\begin{array}{c}\text { Exact Sig. } \\
\text { (2-sided) }\end{array}$ & $\begin{array}{c}\text { Exact Sig. } \\
\text { (1-sided) }\end{array}$ \\
$\begin{array}{l}\text { Pearson Chi- } \\
\text { Square }\end{array}$ & $8,185^{\mathrm{a}}$ & 1 &, 004 & & \\
$\begin{array}{l}\text { Continuity } \\
\text { Correction }\end{array}$ & 7,083 & 1 &, 008 & & \\
$\begin{array}{l}\text { Likelihood } \\
\text { Ratio }\end{array}$ & 7,969 & 1 &, 005 & & \\
$\begin{array}{l}\text { Fisher's } \\
\text { Exact Test }\end{array}$ & & & & & \\
$\begin{array}{l}\text { Linear- } \\
\text { by-Linear } \\
\text { Association }\end{array}$ & 8,134 & 1 &, 004 & & \\
$\begin{array}{l}\text { N of Valid } \\
\text { Cases }\end{array}$ & 159 & & & & \\
\hline
\end{tabular}

1. 0 cells $(, 0 \%)$ have expected count less than 5 . The minimum expected count is 12,83 .

2. Computed only for a $2 \times 2$ table

Table 31

The Relationship between the Negotiation of Nurse Managers and Nursing Performance at Harapan Bunda Banda Aceh Hospital in 2015 (n=159)

\begin{tabular}{|c|c|c|c|c|c|c|c|}
\hline \multirow{3}{*}{ No. } & \multirow{3}{*}{$\begin{array}{c}\text { Nursing } \\
\text { Performance }\end{array}$} & \multicolumn{4}{|c|}{ Negotiation } & \multirow{3}{*}{ Total } & \multirow{3}{*}{$\%$} \\
\hline & & \multicolumn{2}{|c|}{ Good } & \multicolumn{2}{|c|}{ Bad } & & \\
\hline & & $f$ & $\%$ & $f$ & $\%$ & & \\
\hline 1 & Good & 120 & 84 & 5 & 31,25 & 125 & 100 \\
\hline \multirow[t]{2}{*}{2} & Bad & 23 & 16 & 11 & 68,75 & 34 & 100 \\
\hline & Total & 143 & 89,9 & 16 & 10,1 & 159 & 100 \\
\hline
\end{tabular}


negotiation skills, while 16 (10.1\%) respondents claimed to have had nurse managers with bad negotiation skills. Among the respondents who claimed to have had nurse managers with good negotiation skills, $120(84 \%)$ respondents showed good performance, while 23 $(16 \%)$ respondents had poor performance. Whereas for respondents who claimed to have had nurse managers with bad negotiation skills, 5 (31.25\%) respondents showed good performance, while 11 (68.75\%) respondents had poor performance. Data analysis to test the research hypothesis on the relationship between the negotiation of nurse managers and the performance of nurses at Harapan Bunda Banda Aceh Hospital in 2015 was conducted using Chi-Square test. The p-value analysis is $(0.000<0.05)$, so $\mathrm{H}_{\mathrm{o}}$ is rejected, and $\mathrm{H}_{\mathrm{a}}$ is accepted, which means that there is a relationship between the negotiation of nurse managers and the performance of nurses.

Table 32

Chi-Square Test

\begin{tabular}{|c|c|c|c|c|c|}
\hline \multicolumn{6}{|c|}{ Chi-Square Tests } \\
\hline & Value & Df & $\begin{array}{l}\text { Asymp. Sig. } \\
\text { (2-sided) }\end{array}$ & $\begin{array}{l}\text { Exact Sig. } \\
\text { (2-sided) }\end{array}$ & $\begin{array}{l}\text { Exact Sig. } \\
\text { (1-sided) }\end{array}$ \\
\hline $\begin{array}{l}\text { Pearson Chi- } \\
\text { Square }\end{array}$ & $23,742^{\mathrm{a}}$ & 1 & ,000 & & \\
\hline $\begin{array}{l}\text { Continuity } \\
\text { Correction }^{\mathrm{b}}\end{array}$ & 20,713 & 1 & ,000 & & \\
\hline $\begin{array}{l}\text { Likelihood } \\
\text { Ratio }\end{array}$ & 19,023 & 1 & ,000 & & \\
\hline $\begin{array}{l}\text { Fisher's Exact } \\
\text { Test }\end{array}$ & & & & ,000 & 000 \\
\hline $\begin{array}{l}\text { Linear- } \\
\text { by-Linear } \\
\text { Association }\end{array}$ & 23,593 & 1 & ,000 & & \\
\hline $\begin{array}{l}\mathrm{N} \text { of Valid } \\
\text { Cases }\end{array}$ & 159 & & & & \\
\hline
\end{tabular}

1. 1 cells $(25,0 \%)$ have expected count less than 5 . The minimum expected count is 3,42 .

2. Computed only for a $2 \times 2$ table 
IJMS 26 (1), 99-145 (2019)

\section{Results}

The data on this research comprised data gathered from two hospitals which totalled 331 respondents (172 respondents from the Tgk. Chik Ditiro Sigli Hospital and 159 respondents from the Harapan Bunda Banda Aceh Hospital) using a questionnaire. The results of this study were obtained using the Mann-Whitney $U$ test to see the difference in the interpersonal communication skills (leadership, communication process, motivation, negotiation) of the nurse managers, and the performance of nurses at two different hospitals. The test results can be seen in Table 33 as follows.

Table 33

The Differences in Interpersonal Communication Skills at Tgk. Chik Ditiro Sigli Hospital and Harapan Bunda Banda Aceh Hospital

\begin{tabular}{|c|c|c|c|c|}
\hline & Hospital & $\mathrm{N}$ & $\begin{array}{l}\text { Mean } \\
\text { Rank }\end{array}$ & $\begin{array}{l}\text { Sum of } \\
\text { Ranks }\end{array}$ \\
\hline \multirow[t]{3}{*}{ Leadership } & $\begin{array}{l}\text { Tgk C.Ditiro } \\
\text { Sigli Hospital }\end{array}$ & 172 & 188.98 & 32504.00 \\
\hline & $\begin{array}{l}\text { Harapan } \\
\text { Bunda } \\
\text { Banda Aceh } \\
\text { Hospital }\end{array}$ & 159 & 141.14 & 22442.00 \\
\hline & Total & 331 & & \\
\hline \multirow[t]{3}{*}{$\begin{array}{l}\text { Process } \\
\text { Communication }\end{array}$} & $\begin{array}{l}\text { Tgk C.Ditiro } \\
\text { Sigli Hospital }\end{array}$ & 172 & 204.37 & 35152.00 \\
\hline & $\begin{array}{l}\text { Harapan } \\
\text { Bunda } \\
\text { Banda Aceh } \\
\text { Hospital }\end{array}$ & 159 & 124.49 & 19794.00 \\
\hline & Total & 331 & & \\
\hline \multirow[t]{3}{*}{ Motivation } & $\begin{array}{l}\text { Tgk C.Ditiro } \\
\text { Sigli Hospital }\end{array}$ & 172 & 170.20 & 29275.00 \\
\hline & $\begin{array}{l}\text { Harapan } \\
\text { Bunda } \\
\text { Banda Aceh } \\
\text { Hospital }\end{array}$ & 159 & 161.45 & 25671.00 \\
\hline & Total & 331 & & \\
\hline
\end{tabular}


IJMS 26 (1), 99-145 (2019)

\begin{tabular}{llccc}
\hline & Hospital & N & $\begin{array}{c}\text { Mean } \\
\text { Rank }\end{array}$ & $\begin{array}{c}\text { Sum of } \\
\text { Ranks }\end{array}$ \\
\hline Negotiation & $\begin{array}{l}\text { Tgk C.Ditiro } \\
\text { Sigli Hospital }\end{array}$ & 172 & 202.83 & 34887.50 \\
& Harapan & 159 & 126.15 & 20058.50 \\
& Bunda & & & \\
& Banda Aceh & & & \\
Hospital & & & 33260.00 \\
Nurse & $\begin{array}{l}\text { Tgk C.Ditiro } \\
\text { Performance }\end{array}$ & 172 & 193.37 & \\
& Sigli Hospital & & & \\
& Harapan & 159 & 136.39 & \\
Bunda & & & \\
& $\begin{array}{l}\text { Banda Aceh } \\
\text { Hospital }\end{array}$ & & & \\
\hline
\end{tabular}

Table 34

Statistical Test

\begin{tabular}{lrrrrr}
\hline & Leadership & $\begin{array}{c}\text { Communication } \\
\text { Process }\end{array}$ & Motivation & Negotiation & $\begin{array}{r}\text { Nurse } \\
\text { Performance }\end{array}$ \\
\hline $\begin{array}{l}\text { Mann- } \\
\text { Whitney U }\end{array}$ & 9722,000 & 7074,000 & 12951,000 & 7338,500 & 8966,000 \\
Wilcoxon & 22442,000 & 19794,000 & 25671,000 & 20058,500 & 21686,000 \\
W & & & & & \\
Z & $-5,595$ & $-9,343$ &,- 978 & $-8,868$ & $-6,399$ \\
$\begin{array}{l}\text { Asymp. } \\
\text { Sig. }\end{array}$ &, 000 &, 000 &, 328 &, 000 &, 000 \\
$(2-$ tailed $)$ & & & & & \\
\hline
\end{tabular}

1. Grouping Variable: Hospital

Table 34 shows that the p-value significance results in leadership variables, communication process, negotiation of the nurse managers, and nurse performance is $0.000(<0.05)$; thus, implying that the null hypothesis $\left(\mathrm{H}_{\mathrm{o}}\right)$ is rejected. It relates that there are differences in the leadership, the communication process, the negotiation of the nurse managers, and the nurses' performance between Tgk. Chik Ditiro Sigli 
Hospital and Harapan Bunda Banda Aceh Hospital. Concurrently, the significance of the p-value on the motivation variable is $0.328(>0.05)$, leading to the acceptance of the null hypothesis $\left(\mathrm{H}_{\mathrm{o}}\right)$. It portrays that there is no difference in the motivation ability of nurse managers at Tgk. Chik Ditiro Sigli Hospital and Harapan Bunda Banda Aceh Hospital.

\section{Discussion}

Based on this study, the result of the relationship between the interpersonal communication skills of the nurse managers and nursing performance at Tgk. Chik Ditiro Sigli Hospital and Harapan Bunda Banda Aceh Hospital and the difference in the interpersonal communication skills between the nurse managers working at Tgk. Chik Ditiro Sigli Hospital and Harapan Bunda Banda Aceh can be drawn as follows. The result reveal significant relationship between nurse manager's leadership, communication process, motivation skills and negotiation skills, with nursing performance. The results of the Mann-Whitney $U$ test showed there are differences in the leadership, communications process, and negotiation skills of nurse managers, and the performance of nurses at Tgk. Chik Ditiro Sigli Hospital and Harapan Bunda Banda Aceh Hospital.

However, there is no difference in the motivation of nurse managers at Tgk. Chik Ditiro Sigli Hospital and Harapan Bunda Banda Aceh Hospital. In accordance with the previous statement by Mangkuprawira and Vitalaya (Yamin, 2010), "Performance is a multidimensional construction that includes many factors that influence it. These factors consist of intrinsic factors (personal/ individual) or human and extrinsic resources, i.e., leadership, system, team, and situation ". The purpose of the above leadership factors include aspects of quality managers and team leaders in providing encouragement, encouragement, direction and support work to employees.

Based on the theory and results of the above findings, it states clearly that the performance of one of the employees influenced by leadership factors. Results of research at Tgk. Chik Ditiro Sigli Hospital shows that the leadership of the nurse managers and performance of nurses is still bad. While in Harapan Bunda Banda Aceh Hospital, 
the results showed that the average nurse managers leadership was good as well as the performance of the nurse. The description of the poor or bad leadership of the nurse managers at Tgk. Chik Ditiro Sigli Hospital is another possibility caused by the individual factor of the nurse managers, that is, the lack of competence of the nurse managers (knowledge, attitudes, and skills) as a leader. The possible lack of competence possessed by the nurse managers as a leader is caused by not getting education and training related to the leadership provided by the hospital to the nurse managers. Based on the data that researchers had obtained at Tgk. Chik Ditiro Sigli Hospital since the period 2013 to 2015, there was no education and training related to leadership given to the nurse managers. Education and training obtained by the nurse managers have been more focused on direct nursing care actions to patients.

Robbins and Hunsaker (Bambacas \& Patrickson, 2008) reviewed a large number of studies and synthesized interpersonal skills that appeared on most lists. This skill consists of three categories, that is, leadership, communication process and motivation. The interpersonal leadership skills relate to leadership styles, conflict management, meeting conditions, team building and promoting change as well as negotiation. Luthans (Novitasari, 2014) assented that "The leadership style is a way to influence other people's leadership/ subordinate such that the person is willing to do the will of leaders to achieve organizational goals although personally, it may be unpopular." Avolio (2005) examined the influence of leadership and member changes on organizational commitment. His research finds that transformational leadership is positively related to the leader-member exchange (LMX) dimension and organizational commitment.

Kanste (2007) did research that aimed to explore the relationship between multidimensional leadership and fatigue among nursing staff. This study was conducted on 601 nurse and nurse managers working in different healthcare organizations. The results of this study seem to protect particularly from depersonalization. Passive laissez-faire leadership functional as an exposing factor for emotional exhaustion as well as a decreasing factor for personal accomplishment. However, the employment status and the character of work tasks affect the connection between leadership and fatigue. With all the changes and growing demand for higher quality, modern products 
and services, many traditional institutions all over the world face closure or difficulties in upgrading (Ahamat et al., 2017). Therefore, the hospital in this context is not excluded from future challenges to remain competitive.

\section{Conclusion}

The results showed that there was a significant relationship between interpersonal communication skills (leadership, communication process, motivation, and negotiation) of nurse managers and the performance of nurses at the two hospitals. Though management research and physical sciences are different in various aspects, there are still ways by which management research can learn from the physical sciences, allowing the issues of the real world in organisations to be addressed via systems thinking. As a suggestion for further research, it could be useful to engage qualitative research by embedding systems thinking to fathom the personal perspective in interpersonal communication skills among employees in selected hospitals. Future studies could consider the qualitative method using interviews and personal observations. As structured interviews and personal observations have led to the discovery of several key emerging themes, which may not have been uncovered as explicitly if only non-qualitative approaches were applied.

\section{References}

A. M., \& Young, C. E. (1994). Transformational leadership: The feminist connection in postmodern organizations. Holistic Nursing Practice, 9(1), 16-25.

Ahamat, A. (2014). Examining how management research learns from research in the physical Sciences. Journal of Law \& Social Sciences, 4(1), 95. DOI 10.7603/s40741-014-0013-2.

Ahamat, A. (2017). Is Islamic banking and finance doing enough? Shaping the sustainable and socially responsible investment community. Asian Social Science. 13(3). DOI:10.5539/ass. v13n3p170.

Ahamat, A. (2019). Using structured interviews and personal observation to study entrepreneurial opportunity: A reflection, SAGE Research Methods Cases. SAGE Publications, London. DOI: https://dx.doi. org/10.4135/9781526490964 
Ahamat, A., Shahkat Ali, M. S.\& Hamid, N. (2017). Factors influencing the adoption of social media in small and medium enterprises (SMEs). International E-Journal of Advances in Social Sciences (IJASOS). 3(8). DOI: 10.18769/ijasos.336544

Aiken, L. H., Clarke, S. P., Sloane, D. M., Sochalski, J., \& Silber, J. H. (2002). Hospital nurse staffing and patient mortality, nurse burnout, and job dissatisfaction. Journal of the American Medical Association, 288,19.

Anderson, E. T., \& Mc Farlane, J. (2007). Keperawatan komunitas, Jakarta: EGC.

Arikunto, S., \& Jabar., Cepi. (2004). Evaluasi program pendidikan: Pedoman teoritis praktis bagi praktisi pendidikan. PT. Bumi Aksara: Jakarta.

Avkiran, N. (2000). Interpersonal skills and emotional maturity influence entrepreneurial style of bank managers. Personal Review, 29(5), 654ñ675.

Avolio, B. J., Weichun, Z., William, K., \& Bhatia, P. (2005). Transformational leadership and organizational commitment: Mediating role of psychological empowerment and moderating role of structural distance. Journal of Organizational Behavior, 25(5), 951-968.

Bambacas, M., \& Patrickson, M. (2008). Interpersonal communication skills that enhance organizational commitment, Journal of Communication Management, 12(1), 51-72

Barrett, D. J. (2006). Strong communication skills a must for todayís leaders. (pp. 385-390). Handbook of Business Strategy, Emerald Publishing.

Bernard Hodes Group. (2006). The 2006 aging nursing workforce survey. New York: Author.

Brice, A. (Summer, 2000). Access to health service delivery for hispanics: A communication issue. Journal of Multicultural Nursing and Health, 6(2), 7-17.

Cakra, S. dkk. (2010). 5(Lima) undang-undang republik Indonesia. BP. Restindo Mediatama: Jakarta.

Chitty, K. K. (2001). Professional nursing, concepts and challenges (3rd ed.). Philadelphia, PA: W. B. Saunders.

Cohen, J., Cohen, P., West, S. G., \& Aiken, L. S. (2013). Applied Multiple Regression/Correlation Analysis for Behavioral Sciences. (3rd ed.) Oxford: Routledge.

Engkoswara., \& Komariah. (2010). Administrasi pendidikan. Alfabeta: Bandung.

Farid, M. (2013). Pengertian perubahan sosial, contoh, dampak, proses, masyarakat, bentuk teori, faktor pendorong dan penghambat. 
IJMS 26 (1), 99-145 (2019)

Retrieved from https//mfarid731.wordpress.com. Akses 4 Oktober 2016.

Gellet, F. J., \& Schalk, R. (2012). Age-relatedAttitudes: The influence on relationships and performance work. Journal of Health Organization and Management, 26(1), 98-117.

Germain, P. P., \& Cumming, G. G. (2010). The influence of nursing leadership on nurse performance: A systematic literature review. Journal of Nursing Management, 18(4), 425-439.

Hafizurrachman, H. M. (2009). Manajemen pendidikan dan kesehatan. Jakarta: Sagung Seto.

Harapan Bunda Hospital. (2015). Company profile. Indonesia: Banda Aceh.

Harmiyati, L. (2016). Pengaruh karakteristik dan kapabilitas individu serta karakteristik organisasi terhadap persepsi kinerja perawat perkesmas di Puskesmas Kota Palembang. Jurnal Kedokteran dan Kesehatan, 3(1).

Hasibuan, M. S. P. (2011). Manajemen sumber daya manusia. Edisi Revisi: Jakarta.

Hochwarter, W. A., Witt, L. A., Tredway, D. C., Ferris, G. R. (2006). The interaction of social skill and organizational support on job performance. Journal of Applied Psychology, 91(2), 482-489.

Houle, J. (2001). Health and safety survey. American Nurses Association. Retrieved from http://www.nursingworld.org Main Menu Categories/ Occupationaland Environmental/ occupational health/ Health Safety Survey.aspx

Hunsaker, P. L. (2002). Training in management skills. Upper Saddle River New Jersey: Prentice Hall.

Ilyas, Y. (2002). Kinerja: Teori penilaian, penelitian (Cetakan Ketiga). Depok:Pusat Kajian Ekonomi Kesehatan FKM UI.

Jalal, O. M. (2012). Siapa itu Generasi Y. Retrieved from https:// manajemenppm.wordpress.com.Akses: 2 Oktober 2016.

Juanita. (2002). Peran kesehatan dalam benchmarking rumah sakit dalam menghadapi krisis ekonomi. Universitas Sumatra Utara.

Kanste, O., Kyngas, H., \& Nikilla, J. (2007). The relationship between multidimensional leadership and among nursing staff. Journal of Nursing Management, 15(7), 731-739.

Katon, G. (2014). Perbedaan antara organisasi pemerintah dan organisasi swasta. Retrieved from Gerrykaton.Blogspot.com.

Kunze, F., Boem, S., \& Bruch, H. (2013). Age, resistance to change, and job performance. Journal of Managerial Psychology, 28(7/8), 741-760. 
Laschinger, H. K., \& Wong, C. (1999). Staff nurse empowerment and collective accountability: Effect on perceived productivity and self-rated work effectiveness. Journal of Nursing Economics, 17(6), 308-317.

Liliweri, A. (2011). Komunikasi: Serba ada serba makna. Jakarta: Kencana Predana Media Group.

Magnus, U. (2009). The success of an organization depends on the manager communication skills [Online]. Available: http//:www.Associated Content.Com.

Marquis, B. L., \& Huston C. J. (2010). Leadership roles and management function in nursing: Theory $\&$ application. USA: Lippincott Williams \& Wilkins.

Matin, H. A., Jandaghi, G., Karimi, F. H., \& Hamidizadeh, A. (2010). The relationship between interpersonal communication skill and organizational commitment (Case Study: Jahad Keshavarzi and University of Qom, Iran). European Journal of Social Sciences, 13(3).

Mikanowicz, C., \& Shank, S. (2009). Communication strategies. National Center of Continuing Education.

Myers. K. K., \& Sadaghian, K. (2010). A communication perspective on millennials organizational relationships and performance, Journal of Business and Psychology, 25(2), 225-238.

Nassar, M. E., Abdou, H. A., \& Mohmoud.N, A. (2011). Relationship between management styles and nursesí retention at private hospital, faculty of nursing, Nursing Administration, Alexandria.

Notoatmodjo, S. (2012). Metodologi penelitian kesehatan. Jakarta: Rineka Cipta.

Novitasari. (2014). Tantangan tingkat usia dan kepemimpinan terhadap Kinerja. Jurnal Jejaring Administrasi Publik, 4(1), 408412.

Nursalam. (2014). Manajemen keperawatan aplikasi dan praktek. Jakarta: Salemba medika.

Omar, K., Mohamed Anuar, M., Abdul Majid, A. H., \& Johari, H. (2012). Organizational commitment and intention to leave among nurses: The mediating role of moral obligation. International Journal of Management Studies, 19(2), 31ñ46.

Page, A. (Ed.). (2004). Keeping patients safe: Transforming the work environment of nurses. Washington, DC: National Academies Press.

Penley, L. E., Alexander, E. R., Jernigan, I. E., \& Henwoo, C. I. (2014). Communication abilities of managers: The relationship to 
performance. Journal Citation Report, Impact Factor: 6,071/ Rangking: Psychology Applied 1 out of 76/ Business out of 115 /Management 4 out of 185.

Pratama, R. (2014). Pengertian rumah sakit dan pelayanan kesehatan. Raypratama.Blogspot.co.id.

Rajan Pillai, T. \& Ahamat, A. (2018). Social-cultural capital in youth entrepreneurship ecosystem: Southeast Asia. Journal of Enterprising Communities: People and Places in the Global Economy, 12(2), 232-255. DOI: https://doi.org/10.1108/JEC-08-2017-0063.

Ridwan. (2005). Metod dan teknik penyusunan proposal penelitian. Bandung: Alfabeta.

Riwidikdo, H. (2012). Statistik kesehatan. Jakarta: Nuha Medika.

Robinson, M. (2006). How to improve your interpersonal communication skills. Retrieved from http://: www. Associated Content.com.

Rogers, A. E., Hwang, W. T., \& Scott, L. D. (2004). The effects of work breaks on staff nurse performance. Journal of Nursing Administration, 34, 512ñ 519 .

Ruppel, C. P., \& Harrington S. J. (2015). The relationship of communication: Ethical work climate and trust to commitment and innovation. Journal of Business Ethics, 25(4), 313-328.

Ruppel, C. P., Harington, S. J (2000). The relationship of communication, ethical work climate, and trust to commitment and innovation. Journal of Business, 25(4), 313-328.

Salanova, M., Agut, S., \& Peiro, J. M. (2005). Linking organization resources and work engagement to employee performance and customer loyalty: The mediation of service climate. Journal of Applied Psychology, 90, 1217-1227.

Salanova, M., Lorente, L., Chambel, M. J., \& Martinez, I. M. (2011). Linking transformation leadership to nursesí extra-role performance: The mediating role of self-efficacy and work engagement. Journal of Advanced Nursing, 67(10), 2256-2266.

Sanders, M. S., \& McCormick, E. J. (1993). Human factors in engineering and design. New York: McGraw-Hill.

Sarwono, J. (2006). Metode penelitian kuantitatif dan kualitatif. Graha Ilmu: Yogyakarta.

Siagian, S. P. (2009). Manajemen sumber daya manusia. PT Bumi Akasara: Jakarta.

Smith, M. (2009). Essential business skills for project managers [Online] Available: http://www. AssociatedContent.com.

Subramani, S. P. V. (2011). A study on link between workplace environment and employee performance at big bazaar, 
Chennai (Unpublished Master dissertation). Sona College of Technology.

Sugiyono. (2013). Metodologi penelitian administrasi. CV Alfabeta: Bandung.

Tebbitt, B. V. (1993). Demystifying organizational empowerment, Journal of Nursing Administration, 23(1), 18-23.

Ulrich, R., Quan, X., Zimring, C., Joseph, A., \& Choudhary, R. (2004). The role of the physical environment in the hospital of the 21st century: A once-in-a-lifetime opportunity (Rep. to the Center for Health Design for the Designing the 21st Century Hospital Project). Retrieved April, 30, 2009, from http://www.healthdesign.org/ research/reports/pdfs/role_physical_env.pdf

Unalan, D., \& Tengilimoglu, D. (2009). An empirical study tomeasure the communication skills of the manager assistants medical secretaries and office workers in the public sector. The Journal of American Academy of Business Cambridge, 14(2), 245-250.

Unange Passé, A. (2008). Mastering interpersonal communication skills. Retrieved from http//:www.AssociatedContent.com.

Usman, H. (2009). Manajemen teori, praktik dan riset pendidikan. Jakarta: Bumi Aksara.

Veithzal, R., \& Murni, S. (2009). Education management, analisis teori dan praktik. Jakarta: Rajawali Pers.

Veithzal. R et. al. (2008). Performance appraisal. Jakarta: Rajawali Pers.

Wahyudi. (2008). Manejemen konflik. Bandung. Alfaeta.

Werner, J. M., \& Desimore, R. (2006). Human resource development. USA: Thomson.

Wibisono, D. (2006). Manajemen kinerja: Konsep, desain, dan tehnik meningkatkan daya saing perusahaan. Jakarta: Erlangga.

Wibowo. (2007). Manajemen kinerja. Jakarta: PT Raja Grafind Persada.

Winardi.(1994). Manajemen konflik (konflikperubahan danpengembangan). Bandung: Mandar Maju.

Wirawan. (2009). Evaluasi kinerja sumber daya manusia: Teori, aplikasi, dan penelitian. Jakarta: Salemba empat.

Yamin, M. (2010). Standarisasi kinerja guru. Gaung Persada: Jakarta.

Yaverbaum, E., \& Sherman, E. (2008). Everything leadership book. (2nd ed.). Adam Media: Avon, Massachusetts.

Yulk, G. (1998). Leadership in organization. London: Prentice-Hall. 